\title{
Fen Bilgisi Öğretmen Adaylarının STEM Uygulamaları Hakkındaki Görüşlerinin Belirlenmesi
}

\section{Determination of Pre-service Science Teachers' Views Regarding STEM Applications *}

Fatih ASLAN ${ }^{1}$, Oktay BEKTAŞ ${ }^{2}$

1 Öğretmen, MEB, faslan1010@gmail.com, (iD)0000-0001-6150-5705

2 Doç. Dr., Erciyes Üniversitesi, obektas@erciyes.edu.tr, (D)0000-0002-2562-2864

\begin{tabular}{|c|c|c|c|c|}
\hline \multicolumn{5}{|c|}{ Araştırma makalesi/ Research Article } \\
\hline Geliş: 13.11.2019 & 紫 & Kabul: 01.12.2019 & 年 & Yayın: 31.12.2019 \\
\hline \multicolumn{5}{|c|}{$\begin{array}{l}\text { Atıf } \\
\text { Aslan, F. \& Bektaş, O. (2019). Fen bilgisi öğretmen adaylarının STEM uygulamaları hakkındaki } \\
\text { görüşlerinin belirlenmesi. Maarif Mektepleri Uluslararası Eğitim Bilimleri Dergisi, 3(2), 17-50. }\end{array}$} \\
\hline
\end{tabular}

Öz

$\mathrm{Bu}$ çalışma fen bilgisi öğretmen adaylarının STEM uygulamaları hakkındaki düşüncelerini incelemek amacıyla yürütülmüştür. Çalışmada nitel araştırma yöntemi kullanılmış, desen olarak ise fenomenoloji tercih edilmiştir. Amaçlı örneklem yönteminin bir çeşidi olan ölçüt örneklemesine göre katılımcılar seçilmiştir. Ölçüt olarak ise STEM eğitimine katılmamış öğrenciler belirlenmiştir. Araştırmanın çalışma grubunu 2018-2019 eğitim-öğretim yılında bir devlet üniversitesinde öğrenim gören üçüncü ve dördüncü sinıf fen bilgisi öğretmen adayları oluşturmuştur. Dört kadın ve beş erkek katılımcı ile yarı yapılandırılmış görüşmeler gerçekleştirilmiştir. Dolayısıyla, çalışmada veri toplama aracı olarak 13 açık uçlu sorudan oluşan yarı yapılandırılmış görüşme formu kullanılmıştır. Görüşmeler sakin bir odada karşılıklı yüz yüze yapılmış ve katılımcılardan izin alınarak görüşmeler ses kaydına alınmıştır. Ses kayıtları yazıya döküldükten sonra kodlar, kategoriler ve temalar oluşturularak içerik analizi yapılmıştır. Doğrudan alıntılar yapılarak bulgular sunulmuştur. Çalışma sonucunda fen bilgisi öğretmen adaylarının fen bilimlerini birçok disiplinle ilişkilendirdikleri

\footnotetext{
* Bu makale yüksek lisans tez çalışmasından elde edilmiştir
} 
görülmüştür. Ayrıca, STEM kavramını tanımlayabilecek yeterlikte oldukları ve STEM uygulamalarının ortaokul fen bilgisi öğretim programına entegre edilmesi gerektiğini düşündükleri belirlenmiştir. İlave olarak, katılımcılar STEM uygulamalarının öğrenci ve öğretmen açısından birçok olumlu yönlerinin olduğunu ifade etmişlerdir. Son olarak katılımcılar STEM uygulamalarının alt yapı sıkıntısı ve maddi açıdan olumsuz yanlarının da olabileceğini belirtmişlerdir. Bu bulgulardan hareketle STEM uygulamalarının anlamlı öğrenmeyi destekleyecek nitelikte olduğu ve ortaokul fen bilimleri öğretim programında bir ders olarak okutulması gerektiği sonucuna ulaşılmıştır. Bu sonuçlardan yola çıkarak fen bilgisi öğretmenliğinden mezun olan öğretmen adaylarının STEM uygulamaları hakkında ileri düzeyde görüş sahibi olmaları için eğitim fakültesindeki, öğretim programının STEM uygulamaları ile desteklenmesi gerektiği önerilmiştir.

Anahtar Kelimeler: STEM, fen eğitimi, nitel araştırma, fenomenoloji

\section{Abstract}

This study was conducted to examine the pre-service science teachers' opinions about STEM applications. Qualitative research method was used in the study and phenomenology was preferred as the design. Participants were selected according to criterion sampling which is a kind of purposive sampling method. Students who did not participate in STEM education were determined as the criteria. The study group consisted of third and fourth grade pre-service science teachers studying at a state university in 2018-2019 academic year. Semi-structured interviews were conducted with four female and five male participants. Therefore, a semi-structured interview form consisting of 13 open-ended questions was used as a data collection tool. The interviews were held face-to-face in a quiet room and the researcher was allowed to record the interviews. After the sound recordings were transcribed, content analysis was performed and codes, categories and themes were created to write findings. Direct quotations were used to present findings. As a result of the study, it was seen that pre-service science teachers associate science with many disciplines. In addition, they were able to define the concept of STEM and they thought that STEM applications should be integrated into the science curriculum. Besides, the participants stated that STEM practices have many positive aspects in terms of students and teachers. Finally, participants expressed that STEM activities have some negative sides such as technological barriers and financial problems. Based on these findings, it has been concluded that STEM practices should support meaningful learning and should be taught as a course in science curriculum. Based on these results, it was proposed that the curriculum of the faculty of education should be supported with STEM applications since the pre-service science teachers can have advanced views on STEM applications.

Keywords: STEM, science education, qualitative research, phenomenology

\section{Giriş}

Son yıllarda güncellenen eğitim öğretim programlarında fen eğitiminin hedefleri de kritik değişiklik göstermiştir. $\mathrm{Bu}$ amaç doğrultusunda, bilimsel bilgilerin kazanılmasında öğrencilerin aktif rol oynaması gerektiği fikri değişiklik olarak benimsenmiştir (Milli Eğitim Bakanlığı [MEB], 2009). Bilgi çağı, kendine düşen görevin farkında olan, kritik düşünebilen, karşılaştığı problemlere yönelik fikirler üretebilen bireylerin yetiştirilmesini gerekli kılmaktadır (Dağ, 2016). Bu durumda öğretim programlarına büyük görevler düşmektedir. 
Türkiye' de 2004 yılında öğretim programlarında büyük bir değişikliğe gidilerek yapılandırmacı yaklaşım modeli benimsenmiştir. Yapılandırmacı yaklaşım sayesinde derslerde aktif olan öğretmenin yerini öğrenci almış ve öğretmen yol gösterici, rehber pozisyonu almıştır. Öğrenci aktif olduğu için sürece doğrudan dahil olmaktadır. Yapılandırmacı yaklaşımda kişi eski bilgilerini yeni bilgileri ile karşılaştırır ve eski bilgilerin yerine yeni bilgilerin gelmesi için zihninde yeni şema oluşturarak daha kalıcı bilgilere ulaşır (Özmen, 2015).

İlerleyen yıllarda bu değişiklikler devam etmiş 2017 ve 2018 yıllarında güncellenen fen bilimleri öğretim programının vizyonuna bakıldığında, yapısı kullanılan programla benzer içeriklere sahip olmasına rağmen program incelendiğinde bazı yeni eklemeler göze çarpmaktadır. Göze çarpan en önemli farklılık "fen, mühendislik ve girişimcilik uygulamaları" ve "mühendislik ve tasarım becerileri" 'nin programa eklenmesidir (MEB, 2017; MEB, 2018). 2013 fen bilimleri öğretim programında "araştırma-sorgulama stratejisi" öne çıkarken, 2017-2018 yılındaki programlarda ise "araştırma-sorgulama ve bilginin transferine dayalı strateji" ön plandadır (MEB, 2013; MEB, 2017; MEB, 2018).

Yapılandırmacı yaklaşım ile yenilikçi öğretim yaklaşımlarından biri olarak görülen STEM eğitim yaklaşımının ilişkisini ortaya koyan alan yazında çeşitli çalışmalar bulunmaktadır (Selvi ve Yıldırım, 2017; Seren ve Veli, 2018; Yıldırım, Şahin ve Tabaru, 2017). Bu çalışmalarda STEM eğitiminin felsefi temelleri, yukarıda bahsedilen yapılandırmacı yaklaşımın temelleri de dikkate alınarak, yapılandırmacı yaklaşıma dayandırılmaktadır.

STEM denilince herkesin aklına aynı kavramlar gelse de STEM'e farklı araştırmacılar tarafından çeşitli anlamlar yüklenmektedir. Alan yazın incelendiğinde araştırmacıların STEM eğitimine dair tanımları aşağıdaki şekilde yer almaktadır. Bybee (2010) STEM'i fen, teknoloji, matematik ve mühendislik alanlarının birbirleri ile iş birliği içerisinde olmasını hedefleyen bir öğretim sistemi olarak tanımlamıştır. Barakos, Lujian ve Strang'ın (2012) yapmış olduğu çalışmada ise STEM'in öğretme ve öğrenme ortamlarında fen, teknoloji, mühendislik ve matematik alanlarının entegre edilmesi ile ortaya çıkan bir öğretim yaklaşımı olduğundan söz edilmiştir. Yapılan başka bir araştırmada Çorlu (2014), STEM'in öğretme-öğrenme ortamları için fen, teknoloji, mühendislik ve matematik konularını ve becerilerini bütün yapılar halinde veren bir yaklaşım olduğunu göz önüne çıkarmaktadır.

STEM son yıllarda popülerliğini artırarak yeni bir kavrammış gibi görünse de doğuşu 1950 ve 1960 yıllarına dayanmaktadır. Bu yıllar arasında Sputnik isimli uzay aracının uzaya fırlatılması sonucu Amerikalı politikacılar, bilim insanları ve öğrenciler bilim ve teknolojiye daha fazla ilgi duymaya başlamışlardır. Fakat yapılan uluslararası sınavlarda öğrencilerin başarısızlıkları devam etmiş ve Amerika birçok Avrupa ülkesinin gerisinde kalmıştır (Baldi, Jin, Skemer, Green, \& Herget, 2007). Bu süreçten sonra Amerikalı yetkililer eğitim başta olmak üzere birçok alanda zayıf olduklarını tespit etmişler ve eğitimciler, bilim insanları ve matematikçiler başta olmak üzere bir 
eğitim reformu oluşturmak için harekete geçmişlerdir (Bybee, 2013). Bu reform sonucunda Amerika öğrencilerin fen derslerine olan ilgilerini artırmak ve fen derslerini eğlenceli hale getirmek amacıyla 1990'lı yıllarda disiplinler arası bir yaklaşımın temellerini atmıştır (Sanders, 2009). Sanders, bu süreci şöyle özetlemiştir; fen, teknoloji, mühendislik ve matematik bilimini entegre eden bir yaklaşım ortaya koyularak SMET olarak adlandırılmış ve Amerikan Ulusal Bilim Kurumu tarafından 2000'li yıllarda bu yaklaşım STEM olarak anılmaya başlanmıştır. Aslında ilk kısaltma SMET olarak önerilmiş ancak bu kısaltmanın SMUT kelimesiyle olumsuz ilişkisi üzerine tartışmalar sonucunda STEM kısaltmasına karar verilmiştir (Bybee, 2013). Bu bilgiler ışığında STEM uygulamalarının temel gayeleri arasında öğrencilerin enerji ve ilgilerini topluma yön verebilecekleri şekilde yönlendirmek, değişik ortamlarda bulunabilmeleri için fırsatlar oluşturmak ve öğrencileri öğrenme için ilgilerini artıracak soru ve problemlerle karşı karşıya koymak yer alır. STEM uygulamalarının diğer bir gayesi ise, disiplinler arasında birlik sağlamak ve iş birliğini uyumlu bir şekilde ortaya çıarmaktır (Wang, 2012). Bunun yanı sıra, STEM uygulamaları ile ilköğretim ve ortaöğretim okullarında öğrenim gören merak duygusu fazla, nedensonuç ilişkisi kurabilen, yetenekli öğrencilerin belirlenmesi ve bu öğrencilerin üniversitelerin Fen, Teknoloji, Mühendislik ve Matematik alanlarına yönlendirilmesi hedeflenmektedir.

Amaçlardan da anlaşılacağı gibi STEM eğitimi, öğrencilerin okullarda öğrendiği teorik bilgileri pratiğe çevirerek ürün ortaya çıkarabilmesi açısından önemlidir. $\mathrm{Bu}$ düşüncelere benzer olarak Çorlu ve Çallı (2017) çalışmasında STEM eğitiminin öğrenmeyi okul ile sınırlamadığını, toplumun bilim toplumuna dönüşmesini sağladığını, öğrencilerin icatlar yapma ihtimallerini artırdığını ve üretime katkı veren öğrenciler yetiştirdiğini ifade etmektedir.

STEM eğitimi ile ilgili uygulama yaklaşımlarına bakıldığında, disiplinlerin ayrı ayrı ele alındığı veya en az iki disiplinin birbiriyle ilişkili olarak (bütünleşik) uygulamaların yapıldığı görülmektedir (Morison, 2006). Türkiye'de yapılan STEM alanı ile ilgili çalışmaların "Bütünleşik STEM" uygulamaları şeklinde olduğu söylenebilir. Bütünleşik STEM eğitimi, STEM okuryazarı bireyler yetiştirmeyi amaçlayan, temeli disiplinler arası yaklaşıma dayanan bir eğitim stratejisidir (Thomas, 2014). Alan yazın incelendiğinde Sanders ve Welss, (2010) yaptığı çalışmada ise bütünleşik STEM eğitimin, teknoloji ve mühendislik eğitiminin içeriği ile fen ve matematiğin bütünleşmesi şeklinde tanımlamaktadır. Bütünleşik STEM eğitimi, öğrencileri daha iyi problem çözen, yenilikçi, yaratıcı, özgüvenli, mantıksal düşünen ve teknoloji okuryazarı bireyler yapar (Morrison, 2006). Aynı şekilde Sanders (2012)'e göre ise, STEM eğitimi alan öğrenciler, bütünleşik STEM bilgi ve becerilerini özgün problemlerin çözüm sürecindeki aşamalarda kullanabilir, STEM alanlarına tutumunu ve eğilimini sergileyebilir. Böylece öğrenciler değişen çağa uyum sağlar ve karşılaştıkları zorluklara kolaylıkla çözüm üretebilirler. 
Her ne kadar bütünleşik STEM birçok alan ile entegre halinde olsa da birçok araştırmacı temelde doğa bilimleri, matematik, mühendislik ve teknoloji üzerinde durmuşlardır (Kuenzi, Matthews ve Mangan, 2006).

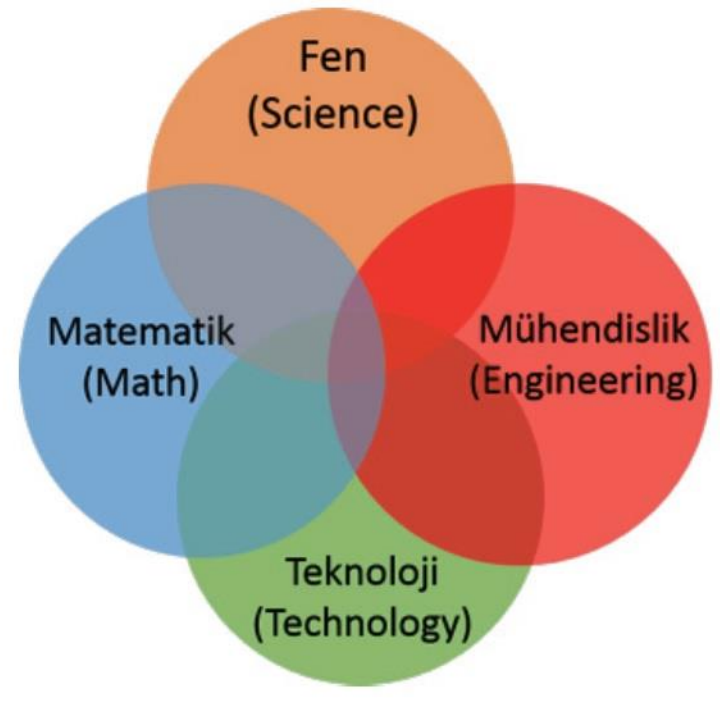

Şekil 1. Bütünleşik STEM alanları (Akgündüz, Ertepınar, Ger, Kaplan ve Türk, 2015)

$\mathrm{Bu}$ bilgiler ışığında gelecek yıllarımızın programlarını uygulayacak olan bugünün öğretmen adaylarının ülkemizi her alanda üst seviyelere çıkarmaları açısından alacakları eğitimler önemlidir. Ayrıca, onların yapacakları çalışmalar parlak bir gelecek açısından oldukça önemlidir.

Türkiye' de yapılan araştırmalar incelendiğinde STEM eğitimi ile ilgili öğretmen adayları üzerine yapılan çalışmalara rastlanmaktadır. Alan yazında konu ile ilgili; fen bilgisi öğretmen adayları (Bozkurt Altan, Yamak ve Buluş Kırıkkaya, 2016; Hacıoğlu, Yamak ve Kavak, 2017; Yıldırım ve Altun, 2015), matematik ve fen bilgisi öğretmen adayları (Yenilmez ve Balbağ, 2016; Yılmaz ve Pekbay, 2017), fen bilgisi öğretmenleri ve fen bilgisi öğretmen adayları ile (Yıldırım ve Altun, 2015) yapılan çalışmalar bulunmaktadır. Öğretmen adayları ile yapılan çalışmalarda ise; STEM ve etkinliklerine yönelik öğretmen ve öğretmen adaylarının görüşleri, STEM farkındalı̆̆ı, STEM'e yönelik tutum, mühendislik dizayna bakış açıları, eleştirel düşünme eğilimleri, bilimsel süreç becerileri ve bilimsel yaratıcılık becerileri incelenmiştir (Alan, 2017).

Ayrıca Gülgün, Yılmaz ve Çağlar (2017), STEM aktivitelerinde bulunması gereken nitelikler öğretmen görüşlerini değerlendirmek istediği çalışmasında "STEM Uygulamaları Kalite Standartları Ölçeği" ve yarı yapılandırılmış görüşme formu kullanılmış çalışma sonucunda fen bilimleri öğretmenlerinin STEM hakkındaki görüşlerinin olumlu yönde olduğunu fakat STEM' in uygulanabilir olması için gereken şartların henüz ülkemizde yeterince uygulamaya geçirilemediğini ifade etmiştir. Aynı şekilde İnançlı ve Timur (2018), yapmış olduğu çalışmada öğretmen adayları ve öğretmenlerin STEM eğitimi hakkındaki görüşleri üzerine durmuşlardır. Çalışma 
sonucunda ise öğretmen adaylarının henüz yeni olan STEM eğitimine karşı bilgi düzeylerinin öğretmenlere oranla daha fazla olduğu gözlemlemiş ve fen bilimleri öğretmen adayları ile öğretmenlerinin STEM eğitimini öğrenmeye karşı istekli olduğu görülmüştür.

Yukarıdaki çalışmalarda da görüldüğü gibi öğretmen ve öğretmen adayları STEM uygulamaları konusunda sıkıntı çekmektedirler fakat fen programının amaçlarına ulaşabilmesi için STEM kavramının öğretmen ve öğretmen adayları tarafından doğru bir şekilde özümsenmesi gerekir. Fen programlarının amaçlara ulaşabilmesinde önemli bir yere sahip olan STEM uygulamalarının gelecek nesillere öğretilebilmesi için fen bilgisi öğretmenlerinin üniversitede aldıkları eğitim ile STEM kavramına doğru bir şekilde hâkim olması gerekmektedir. Bu anlamda, fen bilgisi öğretmen adaylarının STEM uygulamaları hakkında üniversitede aldıkları eğitimöğretim önemlidir. Fen bilgisi öğretmen adaylarının STEM uygulamalarına yönelik görüşlerinin derinlemesine ve kendi gerçekliğinde araştırılmasının üniversite sınavlarına hazırlanan adaylara üniversite tercihlerinde yol gösterebileceği gibi, bu çalışmada yer alan üniversitelere de uyguladıkları fen eğitimi ile ilgili dönütler vereceği düşünülmektedir. Ayrıca bu çalışmanın bir başka önemi de öğretmen adaylarının eğitimine, eğitim fakültelerine ve eğiticilere de kullandıkları sisteme dair geri dönüşler sağlayıp bu dönüşler yardımıyla gerekli düzenlemeleri uygulamalarına olanak sağlayabilmesidir.

$\mathrm{Bu}$ çalışma sonucunda fen bilgisi öğretmen adaylarının STEM uygulamaları hakkındaki düşüncelerine yönelik bir görüşme formu düzenlenip veriler elde edilmeye çalışılmıştır. Ensari (2017), öğretmen adaylarının STEM uygulamalarını hakkında görüşlerini belirlediği çalışmasında öğretmen ve öğretmen adayları ile yapılacak olan çalışmaların okullarda STEM algısını artıracağını belirtmiştir. Başka bir çalışmada ise Gökbayrak ve Karışan (2017), altıncı sınıf ortaokul öğrencilerinin STEM uygulamaları hakkında görüşlerini aldığ çalışmada öğretmenlerin ve öğretmen adaylarının da görüşlerinin alınmasını gerektiğini belirtmiştir. $\mathrm{Bu}$ görüşler araştırmanın önemini ve gerekliliğini destekler niteliktedir.

Bu çalışmada STEM açısından sadece okudukları ve duydukları yönünden deneyim kazanmış öğretmen adayları ile çalışılmıştır. STEM eğitimini direkt deneyimlemiş öğretmen adayları dışında, almayan ama STEM hakkında birtakım algılara sahip öğretmen adaylarının seçilme sebebi onların STEM ile ilgili ön yargılarının olup olmadığını, STEM eğitimi almış öğretmen adaylarından ne derecede farklı olduklarını ve bu durumun gelecek yaşantılarına ne derecede bir etki yapacağını araştırmak içindir. Ayrıca bu araştırma, STEM uygulamaları hakkında öğretmen adaylarının ne düşündükleri araştırılarak, fen programının amaçlarına ulaşabilmesi yönünde fen eğitimcilerine ve fen bilimleri öğretmenlerine bir farkındalık yaratılacaktır. Tüm bu sebeplerden dolayı elde edilen verilerin alan-yazın açısından anlamlı ve değerli olacağ sorusu "Fen bilgisi öğretmen adaylarını STEM uygulamalarına yönelik görüşleri nelerdir?" şeklindedir. 


\section{Yöntem}

\section{Araştırma Deseni}

Bu çalışma kapsamında, bir olguya ayrıntılı anlam kazandırmak ve incelemek amacıyla nitel araştırma yöntemi ve bu araştırma yöntemine ait bir desen olan fenomenoloji kullanılmıştır. Fenomenoloji, detaylı bilgi sahibi olmadığımız olgulara odaklanmaktadır. (Yıldırım ve Şimşek, 2013).

Fen bilgisi öğretmen adaylarının görüşme sorularına verdikleri cevaplardan yola çıkarak eğitim fakültelerinde STEM'in uygulanması, STEM uygulamaları dersini gerekliliği, STEM uygulamalarının öğretmen ve öğrenci açısından avantaj ve dezavantajları gibi konulardaki olguları ayrıntılı bir şekilde ortaya koymak için bu desen tercih edilmiştir. Ayrıca katılımcıların belirttikleri görüşlerden hareketle STEM kavramına dikkatleri çekmek için fenomenoloji deseni kullanılmıştır. Bu bilgiler ışığında yapılan çalışmada öğretmen adaylarının STEM uygulamalarına ilişkin görüşleri belirlemek amaçlandığı için bu desen tercih edilmiştir.

\section{Çalışma Grubu}

$\mathrm{Bu}$ çalışmada amaçlı örneklem kullanılmıştır. Amaçlı örneklem; seçim için önemli olduğu varsayılan ölçütler belirlenmiş ve bu ölçütlere göre seçilen örneklemin, araştırma evreninin bütün niteliklerini temsil ettiği düşünülmektedir (Tavşancıl ve Aslan, 2001). Amaçlı örneklemin türü olan ölçüt örneklem tercih edilmiştir. Ölçüt örneklemde ölçütler belirlenir ve bu ölçütlere uyan bütün olasılıklar çalışlır. Burada bahsedilen ölçüt ya da ölçütler araştırmacının kendi oluşturduğu ya da daha önceden hazırlanmış bir ölçüt listesi olabilir (Yıldırım ve Şimşek, 2013). Buna göre çalışmanın katılımciları İç Anadolu Bölgesi'nde bulunan bir devlet üniversitesinde 2018-2019 eğitim-öğretim döneminde eğitim gören üçüncü ve dördüncü sınıf öğrencilerinden seçilmiştir. Ölçüt olarak STEM eğitimine katılmamış öğrenciler seçilmiştir. Görüşme yapılan dokuz öğrenci Ece, Oya, Ata, Ali, Nur, Alp, Efe, Can ve Ela şeklinde kodlanmıştır. Görüşme esnasında sorulan demografik sorular eşliğinde katılımcıların özellikleri belirlenmiştir. Katılımcların özellikleri Tablo 1'de gösterilmektedir.

Tablo 1. Kattlimclara ait bilgiler

\begin{tabular}{lll}
\hline Katılımc1 & Sinıf & Cinsiyet \\
\hline Nur & 3 & Kadın \\
Ela & 4 & Kadın \\
Ece & 3 & Kadın \\
Oya & 4 & Kadın \\
Efe & 4 & Erkek \\
Can & 3 & Erkek \\
Ata & 3 & Erkek \\
Ali & 3 & Erkek \\
Alp & 4 & Erkek \\
\hline
\end{tabular}




\section{Veri Toplama Araci}

Bu çalışmada öğrenimine devam eden fen bilgisi öğretmenliği üçüncü ve dördüncü sınıf öğretmen adaylarının STEM uygulamalarına yönelik görüşlerinin neler olduğu yarı yapılandırılmış görüşmeler yapılarak belirlenmeye çalışılmıştır. Araştırmacının katılımcılarla yüz yüze gerçekleştirdiği görüşmeler yaklaşık 30 dakika sürmüştür ve yapılan görüşmeler, katılımcıların onayı alınarak ses kayıt cihazıyla kaydedilmiştir. Görüşme soruları araştırmacı tarafından alan yazın incelenerek (Altan, Yamak ve Buluş Kırıkkaya, 2016; Eroğlu ve Bektaş, 2016; Gökbayrak ve Karışan, 2017; MEB 2016) oluşturulmuştur. Görüşme soruları alanında uzman iki fen eğitimcisinin kontrolüne sunulmadan önce 17 sorudan oluşmaktaydı. Uzman fen eğitimcileri tarafından belirli soruların aynı amacı ölçmesi ve bazı soruların amaca uygun olmaması nedeniyle sorularda gerekli düzeltmeler yapılmış ve form son halini almıştır. Görüşme formunun son hali 13 sorudan oluşmaktadır. Görüşme soruları Ek 1'de sunulmuştur.

\section{Verilerin Toplanması}

Veriler toplanmadan önce çalışmanın yapılacağı üniversitenin "Matematik ve Fen Bilimleri" anabilim dalı başkanı ile ön görüşmeler yapılmıştır. Buradaki amaç resmi izinler alınmadan önce fen bilgisi anabilim dalı ders programlarını, öğrencilerin güncel durumlarını öğrenip veri toplama sürecini bu faktörleri göz önünde bulundurarak planlamaktır. Böylece veri toplama sürecinde yaşanabilecek aksaklıkların önüne geçilmiştir. Ön görüşme sonucunda alınan olumlu dönüt sonrası resmi izinler alınmıştır. Veriler 2018-2019 eğitim-öğretim yılının bahar döneminde toplanmış ve verilerin toplanması süreci üç hafta sürmüştür.

Araştırmacı tarafından katılımcılarla okul ortamında, sohbet havasında yüz yüze konuşacak biçimde oturmaya dikkat edilmiş ve kimsenin rahatsız edilmemesi için görüşmeler sessiz ve sakin bir odada gerçekleştirilmiştir. Görüşme esnasında dikkat dağınıklı̆̆ını önlemek amacıyla odada bulunan gereksiz eşyalar azaltılmıştır. Görüşmeler yaklaşık 30 dakika sürmüştür ve yapılan görüşmeler, katılımcıların onayı alınarak ses kayıt cihazıyla kaydedilmiştir. Görüşme sonunda katılımcılara ses kayıtları dinletilerek kontrol ettirilmiştir.

\section{Verilerin Analizi, Geçerlik ve Güvenirlik}

Çalışmada yarı yapılandırılmış görüşmeler ile ulaşılan ses kayıtlarının dökümanize edilmesinin sonrasında görüşmeden elde edilen verilerin ayrıntılı bir şekilde analizi amacıyla ve önceden açıkça belli olmayan görüşlerin ve kapsamların ortaya çıkarılması hedefiyle nitel veri analizlerinden birisi olan içerik analizi tercih edilmiştir. İçerik analizinde temel amaç, verilerden yola çıkarak kavramlar arası ilişkileri açıklayabilecek kod, tema ve kategorilere ulaşmaktır. (Marshall ve Rossman, 2006; Yıldırım ve Şimşek, 2013). 
Görüşmelerden elde edilen veriler 1şığında araştırmacı tarafından kodlamalar yapılarak kategoriler ve bu kategoriler 1şı̆̆ında temalar oluşturulmuştur. Kod, kategori ve temalar oluşturulduktan sonra alanında uzman iki fen eğitimcisinin görüşlerine sunulmuş, uzmanın görüşleri sonucunda veriler temalar ve kategoriler altında sınıflanarak okuyucu için anlamlı hale getirilerek kod ve temaların son şekli verilmiş ve böylece iç tutarlılık sağlanmaya çalışılmıştır. Bulgular bölümündeki soru başlıkları "STEM" temasını oluşturmaktadır. Fen bilgisi öğretmen adaylarının sorulara vermiş oldukları cevaplardan yola çıkarak STEM kavramını nasıl tanımlarsınız? Örnek verebilir misiniz? sorusuna ilişkin STEM tanımı ve STEM örneği olarak kategorilere ayrılmıştır. Bu sınıflamada STEM kavramını açıklayanlar STEM tanımı kategorisine, STEM kavramına örnek verenler ise STEM örneği kategorisi altına alınmıştır.

Çalışmamızda STEM adı verilen tek tema yer alırken bu temalar ışı̆̆ında on beş farklı kategori oluşturulmuştur. STEM temasını disiplinler, STEM tanımı ve STEM örneği, fakülte derslerinde STEM'in uygulanması, STEM uygulaması dersinin gerekliliği, STEM eğitimi, meslek hayatımıza katkısı, motivasyona etkisi, uygun dersler, uygun olmayan dersler, fen konuları, uygulamanın olumlu olumsuz yanları, uygulamanın olumlu yanları, mesleğe katkıları, öneriler kategorileri oluşturmuştur.

Çalışmanın geçerlik ve güvenirliği azaltan bazı durumları azaltmak amacıyla araştırmacı bazı önlemler almaya çalışmıştır (Bektaş ve Eroğlu, 2016; Yıldırım ve Şimşek, 2013). Bu durumlar aşağıda belirtilmiştir.

İç geçerlik, araştırmacı olarak gözlemlediğimiz veya anladı̆̆ımız olgularla ilgili düşüncelerimizin gerçek durumu ile benzerlik derecesi olarak tanımlanmıştır (Yıldırım ve Şimşek, 2013). Bu kapsamda çalışmanın iç geçerliğini yani inandırıcılı̆̆ını artırmak için araştırmacı tarafından uygulanan görüşme formu uzman fen eğitimcilerinin görüşlerine sunulmuştur. Uzmanların görüşleri doğrultusunda araştırmacı tarafından soruların anlaşılabilirliği ve kapsamı gibi hususlar açısından form revize edilmiş ve veri toplama araçları kısmında da bahsedildiği gibi bazı önemli düzeltmeler yapılmıştır. Katılımcılarla yapılan görüşmeler esnasında katılımcıların cevaplarından sık sık teyit alınmıştır. Her bir görüşmenin öncesinde katılımcıyı rahatlatmak adına çalışma hakkında açıklamalar yapılmış ve samimi bir ortamın oluşması için sohbet havası oluşturulmaya çalışılmıştır. Katılımcılardan elde edilen cevaplar doğrudan alıntı yapılarak bulgular kısmında verilmiştir. İç geçerliği sınırlandıran bir etken olarak görüşmenin tek bir veri toplama aracı olarak kullanılması gösterilebilir.

Dış geçerlik, bir araştırma sonuçlarının benzer çevreler ve olaylara uyarlanabilirliği olarak tanımlanmıştır (Yıldırım ve Şimşek, 2013). Dış geçerliliği yani aktarılabilirliği artırmak için ise araştırma deseni, çalışma grubu, veri toplama araçları, elde edilen verilerin analizi ve bulguların nasıl düzenlendiği ayrıntılı bir şekilde ilgili bölümlerde açıklanmıştır. 
Araştırmanın iç güvenirliğini yani tutarlılığını artırmak için ise araştırmanın kod ve temaları alanında uzman fen eğitimcilerinin görüşüne sunularak uzmanlar ve araştırmacı arasında fikir birliğine varılarak tutarlılık sağlanmıştır. Ayrıca görüşme sorularından elde edilen bulgular yorum yapılmadan okuyucuya sunulmuş ve görüşmeler ses kayıt cihazına alınarak veri kaybı önlenerek araştırmanın iç güvenirliği artırılmaya çalışılmıştır.

Araştırmanın diş güvenirliği yani teyit edilebilirliğini artırmak için ise bulgular sonuç-tartışma bölümünde araştırmacı tarafından tartışılmıştır. Ayrıca, araştırmacı ve fen eğitiminde uzman danışman sonuç-tartışma ve bulgular bölümlerinin tutarlılığ1 konusunda fikir paylaşımında bulunmuşlar ve görüş birliğine varmışlardır. Buradan hareketle, dış güvenirliğin bu durumlara bağlı olarak artırılma çalışmaları yapılmıştır.

\section{Bulgular}

Bulgular "STEM" adı verilen tek tema altında verilmiştir. Temalara göre başlıklar belirtilip görüşme sorularına verilen cevaplar tablolar halinde aşağıda belirtilmiştir. $\mathrm{Bu}$ tema başlığı altında on beş kategori ele alınmıştır. Bu kategorilere göre bulgular sunulmuştur. Kategoriler ilgili tablolarda verilmiştir.

Tablo 2. Sizce fen bilimleri hangi disiplinlerle ilişkilidir?" sorusuna ilişkin katılımcı görüşleri

\begin{tabular}{lllllllllll}
\hline KATEGORI & KOD & Nur & Ela & Ece & Oya & Efe & Can & Ata & Ali & Alp \\
\hline & Matematik & $*$ & $*$ & & $*$ & $*$ & $*$ & & $*$ & $*$ \\
& Mühendislik & $*$ & & & & & $*$ & $*$ & $*$ & $*$ \\
& Teknoloji & $*$ & & & & & $*$ & $*$ & $*$ & $*$ \\
& Fizik, Kimya, & & & & $*$ & $*$ & $*$ & & & \\
Biyoloji & & & & & & $*$ & & & \\
Disiplinler & Bütün alanlar & $*$ & & & & & $*$ & & $*$ & \\
& Sosyal bilimler & $*$ & $*$ & & & $*$ & & & & \\
& Doğa bilimleri & & $*$ & & & & & $*$ & & \\
& Sağlik & & & & & & $*$ & & $*$ & \\
Coğrafya & & & & & $*$ & & $*$ & & \\
Yer Bilimi & & & & & & & $*$ & & \\
\hline
\end{tabular}

Tablo 2 incelendiğinde fen bilimlerinin matematik, mühendislik ve teknoloji disiplinleriyle ilişkili olduğunu belirten katılımcı sayısı diğerlerine göre fazladır. Fen bilimlerinin matematik, fizik, kimya, biyoloji disiplinleri ile ilişkili olduğunu belirten Oya bu konu hakkındaki düşüncelerini “...Fizik, Kimya, Biyoloji ve Fen sürekli etkileşim halindedir...Matematikle de ilişkilidir..." şeklinde ifade etmiştir. Diğer katılımcılardan Can ise bütün disiplinlerle ilişkisinin olduğunu mühendislik ve teknoloji ile de iç içe olduğunu belirtmiştir. Düşüncelerini “...fen bütün derslerle konularla ilişkili aslında...biz teorik kısmını fenden sayısal kısmını matematikten tasarım kısmın mühendislikten alabiliriz teknoloji ile de gelişme kısmını alabiliriz..." şeklinde ifade etmiştir. 
Eğitimine 3. sınıfta devam eden Ata ise fen bilimlerinin doğa bilimleri, coğrafya ve yer bilimi ile ilişkilisinin olduğunu belirtmiştir. Bu konu hakkındaki düşüncelerini “...fen bilimleri tüm doğa bilimleri ile sosyoloji ile coğrafya ile ilişkilidir. Bu bilimler arasında doğrudan ilişki vardır..." ifade etmiştir.

Tablo 3. STEM kavramını nasıl tanımlarsınız? Örnek verebilir misiniz?" sorusuna ilişkin katılımcı görüşleri

\begin{tabular}{|c|c|c|c|c|c|c|c|c|c|c|}
\hline Kategori & Kod & Nur & Ela & Ece & Oya & Efe & Can & Ata & Ali & Alp \\
\hline \multirow{4}{*}{ STEM Tanımı } & $\begin{array}{l}\text { Bilim, teknoloji, } \\
\text { mühendislik, } \\
\text { matematik }\end{array}$ & * & & & * & & * & * & & * \\
\hline & $\begin{array}{l}\text { Disiplinler } \\
\text { aras1 etkileşim }\end{array}$ & & & & & * & & & * & \\
\hline & Bütün & & & & $*$ & & & & & \\
\hline & $\begin{array}{l}\text { Birçok alanın } \\
\text { entegre edilmiş } \\
\text { hali }\end{array}$ & & * & & & & & & & \\
\hline \multirow{4}{*}{ STEM Örneği } & Robotik & & $*$ & $*$ & * & * & & $*$ & & \\
\hline & Anahtar sistemi & * & & & & & & & & \\
\hline & Pilli saat & * & & & & & & & & \\
\hline & Mancinık & & & & & & * & & * & \\
\hline
\end{tabular}

Tablo 3 incelendiğinde STEM kavramını katılımcıların tamamının tanımlayıp örnek verdiği görülmüştür. Katılımcılardan Nur, Oya, Can, Ata ve Ali STEM'i tanımlarken bilim, teknoloji, mühendislik ve matematik disiplinlerinden oluştuğunu belirtmişlerdir. Örneğin Nur STEM kavramı hakkında düşüncelerini “...STEM Ingilizce kök manasına geliyor. Bilim, Teknoloji, Mühendislik ve Matematik kelimelerinden oluşmaktadır... Örnek verecek olursam El Cezerinin STEM ile yapmış olduğu pilli saat ve tarihte ilk defa yaptı̆̆ $ı$ kilitlenebilir anahtar sistemini verebilirim..." şeklinde ifade etmiştir.

Katılımcılardan Ela STEM'in birçok alanla etkileşim içerisinde olduğunu belirtmiş ve düşüncelerini "...STEM kavramın birçok alanın entegre edilmiş hali diyebilirim... Örnek verecek olursam robotik kodlama teknolojilerini söyleyebilirim..." cümleleriyle ifade etmiştir.

Diğer katılımclardan Oya ise STEM'in bir bütün olduğunu belirterek düşüncelerini “...Fen, Matematik, Mühendislik ve Teknolojinin karışımı halinde öğrenmiştik ve ben tanım yapacak olursam birçok alanın bir bütün halinde işlenmesidir. Örneğin bir robot tasarlarken STEM den yararlanırız..." şeklinde ifade ederken Can ise düşüncelerini “...STEM kavramı dediğimizde aklımıza fen, matematik, mühendislik ve teknoloji geliyor bunu tanımlarken de hayatımızın her yerinde etki eden etkenler diyebiliriz çünkü nereye baksak ne yapsak aslında STEM'in etkileri var çünkü STEM dediğimiz zaman beş ana dersi gördüğ̈̈̈müz için hayatımızın her yerinde olduğ u için nereye baksak STEM'e rastlayabiliyoruz...Örnek vermek istesem mancınık örneğgini verirdim. Mancını örneğin eski yıllarımızda savaşlarda 
görebiliyorduk bunu öğrencilerimizi aktarabilmek için mancınık etkinliği yaptırılabiliyor STEM adına..." şeklinde ifade etmiştir.

Tablo 4. Fakültedeki alan, laboratuvar ve alan eğitimi derslerinizin STEM uygulamalarn ile işlenmesini ister miydiniz? Neden?" sorusuna ilişkin katılımo görüşleri

\begin{tabular}{lll}
\hline \multicolumn{2}{l}{ Kategori: Fakülte derslerinde STEM'in uygulanması } & \multicolumn{1}{c}{ Kod } \\
\hline Katılımc1 & Evet & Hayır \\
\hline Nur & Kazanım & \\
Ela & Teorikten pratiğe, Üretim & \\
Ece & Teorikten pratiğe & - \\
Oya & Becerilerimizi geliştirme & \\
Efe & Teorikten pratiğe, Kazanım, Üretim & \\
Can & Üretim, Becerilerimizi geliştirme & \\
Ata & Teorikten pratiğe & \\
Ali & Günlük hayatla ilişki kurma, Araştırma & \\
Alp & Teorikten pratiğe, Günlük hayatla ilişki kurma & \\
\hline
\end{tabular}

Tablo 4 incelendiğinde STEM uygulamalarının bilgileri teorikten pratiğe dönüştürdügünü belirten katılımcı sayısı diğerlerine göre daha fazladır. Katılımcılardan Ela, Efe, Ece, Ata, Alp bilgileri teorikten pratiğe dönüştürdüğünü düşünerek Efe bu konu hakkındaki düşüncelerini “...tabi ki isterdim benden sonraki neslin üretken ve milletimize faydalı olmasım isterdim... STEM sayesinde öğrendiklerimiz teorikte kalmaz hayatta daha uygulanabilir üretken fikirler ortaya çıkar..." şeklinde ifade etmiştir.

Diğer katılımcılardan Can ise düşüncelerini “...hazır bilgiyi almadan düşünme becerimizi geliştirirdi, psikomotor becerimizi geliştirirdi..." şeklinde ifade ederken diğer katılımcılardan Ali'nin araştırma ruhunu sahip olacağını belirtmiştir. Bu konu hakkındaki düşüncelerini “...STEM uygulamaları ile dersimizi işlemiş olsaydık şu an herkes araştırma içerisinde olacaktı. Ama bilgiler hazır verildiği için kimse bu zahmette bulunmuyor...araştırma sayesinde bu bilgileri günlük hayatla ilişkilendirmeyi sağlıyor..." şeklinde ifade etmiştir.

Bir diğer katılımcı Nur ise STEM'in birçok kazanımının olduğu düşünerek düşüncelerini “... Kesinlikle isterdim çünkü STEM'in kişiye kazandırdı ğı birçok kazanımlar var ve ilerde biz öğretmen olacağımız için bunu öğrencilerimize de yansıtmamız gerekecek ve bu yüzden kesinlikle isterdim ama yeni yeni oluşacak..." şeklinde ifade etmiştir. 
Tablo 5. Fakültelere "STEM uygulamaları" isimli bir ders fen programına konulmalı mıdır? Neden?" sorusuna ilişkin katılımoı görüşleri

\begin{tabular}{lll}
\hline \multicolumn{2}{l}{ Kategori: STEM uygulamaları dersinin gerekliliği } \\
\hline Katılımcı & \multicolumn{1}{c}{ Kod } & \\
\hline Nur & Evet & \\
Ela & Yapılandırııı, 21. Yüzyıl becerileri \\
Ece & Yapılandırıcı, Üretkenlik & \\
Oya & Öğrencilerin ihtiyacı & Seçmeli ders olmalı \\
Efe & & \\
Can & Çağımızın gerekliliği, Üretkenlik & \\
Ata & Çağımızın gerekliliği & \\
Ali & Çağımızın gerekliliği & \\
Alp & Yapılandırıcı & \\
\hline
\end{tabular}

Tablo 5 incelendiğinde Oya haricindeki bütün katılımcılar STEM uygulamaları isimli dersin fen programina konulması gerektiği söylemişlerdir. Örneğin katılımcılardan Efe çağımızın gerekliliği olduğunu düşünmektedir. Bu konu hakkında düşüncelerini “...bence konulmalı çünkü çă̆ımızın gereklilikleri, üretkenlik ve toplumu daha iyi hale getirmek olduğu için bizim öğretmenlerimizin de bu dersleri alması gerekiyor... bizler gördüğ̈̈müz teorik dersleri STEM uygulamaları ile bir fikri maddesel ortama taşıdığımız zaman biz de onlar gibi üretken nesiller olabiliriz..." şeklinde ifade etmiştir.

Katılımcılardan Nur STEM uygulamalarının hem yapılandırmacı yaklaşım hem de 21. Yy. becerilerini karşıladığını düşünmektedir. Bu konu hakkındaki düşüncelerini “...STEM 21. Yy. becerilerini içerdiği için ve biz de 21. yy. öğretmeni olacağımız için kesinlikle ders programına konulmalıdır... Bilimsel süreç becerilerini kazanmada da STEM 'in çok büyük katkıları olacaktır..." cümleleriyle ifade ederken diğer katılımcı Ela ise düşüncelerini “...Konulmalı şöyle diyebilirim mesela bilimin doğal uygulaması dersinde tek düzeye gitmek yerine birçok alanda mesela çoklu zekaya görsel olarak faydası olacak en çok da uygulamal olduğu için daha çok öğreniyor olacak, uygulamalı olduğu zaman her zaman aktif olunuyor derste aktif olduğun derste daha iyi bir öğrenme oluyor..." şeklinde ifade etmiştir. 
Tablo 1. "STEM eğitimlerinin size ne gibi katkılarının olacă̆ını düşünüyorsunuz? Neden?" sorusuna ilişkin katılımoı görüşleri

\begin{tabular}{|c|c|c|c|c|c|c|c|c|c|c|}
\hline Kategori & Kod & Nur & Ela & Ece & Oya & Efe & Can & Ata & Ali & Alp \\
\hline \multirow{11}{*}{$\begin{array}{l}\text { STEM } \\
\text { Eğitimi }\end{array}$} & Üretken olma & * & & & & * & * & & & * \\
\hline & Ürün ortaya koyma & & & & & 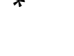 & 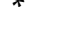 & & & \\
\hline & $\begin{array}{l}\text { Anlatım yönteminde } \\
\text { zenginlik }\end{array}$ & & & & * & & & * & & * \\
\hline & $\begin{array}{l}\text { Problem çözme } \\
\text { becerileri }\end{array}$ & & * & * & & * & & & & \\
\hline & Yaratıcılık & & * & * & & & & & & \\
\hline & Eleştirel düşünce & & * & * & & & & & & \\
\hline & $\begin{array}{l}\text { Öğrenci merkezli } \\
\text { yaklaşım }\end{array}$ & * & & & & & & & * & \\
\hline & $\begin{array}{l}\text { Kendini ifade etme } \\
\text { gücü }\end{array}$ & & & * & & & & * & & \\
\hline & Araştırma & & & & & & * & * & & \\
\hline & $\begin{array}{l}\text { Disiplinler arası } \\
\text { yaklaşım }\end{array}$ & * & & & & & & & & \\
\hline & $\begin{array}{l}\text { Bilimsel süreç } \\
\text { becerileri }\end{array}$ & * & & & & & & & & \\
\hline
\end{tabular}

Tablo 6 incelendiğinde STEM eğitimlerinin öğretmen adaylarına üretken olma ve ürün ortaya koyma alanında katkılarının olacağını düşünen katılımcı sayısı diğerlerine göre fazladır. Örneğin katılımcılardan Alp ise düşüncelerini “...STEM eğitimi benden daha çok ülkemize katkıları olur daha çok teknolojik şeyler yapılabilir çocukların zihinlerinde daha iyi şeyler oluştuğu için daha faydalı şeyler olarak kullanılabilir. Bir şeyler üretme anlamında ülkemize katkılar sağlar..." şeklinde ifade etmiştir.

Katılımcılardan Ece düşüncelerini “...eleştirel düşünme, yaratıcı düşünme, özgüven, problem çözme ve sosyal beceri bunlar açısından tamam iyi yani hem dersler için bu alanlarda geliştirecek hem de normalde..." şeklinde ifade ederken diğer Nur ise bu konu hakkında "...STEM öğrenci merkezli olduğu için ortaya bir ürün koyduruyor hem de disiplinler arası öğrenmeler gerçekleştirdiği için anlamlı öğrenmeyi sağlıyor..." cümleleriyle düşüncelerini belirtmiştir.

Katılımcılardan Can ise düşüncelerini “...STEM eğitimi bizi ilk başta araştırmaya teşvik eder daha sonrasında düşündürür yani çıkarım yapmamıza sebep olur belki ortaya bir ürün koyarak sentez basamağına çıkmış oluruz..." şeklinde ifade etmiştir. Katılımcılardan Ata ise "...kendimi ifade etme gücümün artacă̆ını düşünüyorum..." şeklinde düşüncelerini ifade etmiştir. 
Tablo 2. "Meslek hayatınıza başladığınızda STEM uygulamalarının dersinizde işinizi kolaylaştıracă̆ını düşünüyor musunuz? Neden?

\begin{tabular}{|c|c|c|c|c|c|c|c|c|c|c|}
\hline Kategori & Kod & Nur & Ela & Ece & Oya & Efe & Can & Ata & Ali & Alp \\
\hline \multirow{9}{*}{$\begin{array}{l}\text { Meslek } \\
\text { Hayatımıza } \\
\text { Etkisi }\end{array}$} & Görsel & & * & & & * & & & & \\
\hline & $\begin{array}{l}\text { Öğrenci } \\
\text { merkezli }\end{array}$ & & * & & & & & & * & \\
\hline & Hayata entegre & & & & & * & & & & * \\
\hline & $\begin{array}{l}\text { Soyuttan } \\
\text { somuta }\end{array}$ & & & & & & & * & & \\
\hline & $\begin{array}{l}\text { Bilgisayar } \\
\text { destekli }\end{array}$ & & & & * & & & & & \\
\hline & $\begin{array}{l}\text { Ürün ortaya } \\
\text { koyma }\end{array}$ & * & & & & & & & & \\
\hline & İmkanlar sınırlı & & & * & & & & & & \\
\hline & Alt yapı sorunu & & & & & & * & & & \\
\hline & $\begin{array}{l}\text { Materyal bulma } \\
\text { zorluğu }\end{array}$ & & & & & & & * & & \\
\hline
\end{tabular}

Tablo 7 incelendiğinde STEM uygulamaları ile ders işlendiğinde işlerinin kolaylaşacağını düşünen katılımcılar Ela, Oya, Efe ve Ali iken zorlaşacağını düşünen katılımcılar ise Nur, Ece ve Can'dır. Ata ise hem kolaylaştıracağını hem de zorlaştıracağını düşünmektedir. Kolaylaştıracağını düşünen Ela düşüncelerini “...görsele yönelik olduğu için daha faydalı olacağını düşünüyorum...görsel olarak kendileri öğrenmeleri gereken bir ders için aktif olmaları gerek aktif oldu ŭu içinde model öğrenci merkezli hale dönüşüyor..." şeklinde ifade ederken Oya ise düşüncelerini “...bilgisayar destekli bir okulda evet kolaylaştırır çünkü koşullar da çok önemli..." cümlesiyle ifade etmiştir.

Diğer katılımcilardan Efe ise “...fen bilimlerini hayata entegre edilmiş şekilde öğrencilere aktardığımızda daha görsel olduğundan anlaşılmasının daha kolay olacă̆ın düşündüğ̈̈̈m için işimizi kolaylaştırır..." şeklinde düşüncelerini belirtmiştir. Ali ise düşüncelerini “...tabi kolaylaştırır çünkü baktığımız zaman bir düz anlatımdan biraz daha uzaklaşıyorsun. Daha çok öğrenci merkezli gidiyorsun..." cümleleriyle ifade etmiştir.

STEM uygulamalarının işini zorlaştıracağını düşünen Nur “...dersimi işlemem biraz zor olabilir sonuçta disiplinler arası çalışıyoruz derse girip düz anlatım yöntemiyle anlatmak var bir de STEM ile bütün disiplinleri yoğurup ortaya bir ürün koydurmak var bu bize ilk başlarda zorluk yaşatabilir..." şeklinde düşüncelerini ifade ederken Ece ise düşüncelerini "...imkanlar sınırlı olduğu zaman zorlanmalar olabilir mesela doğu bölgelerinde STEM uygulamaları ile ders işleyen öğretmenlere büyük zorluklar çıkacaktır..." şeklinde ifade etmiştir. İşinin zorlaşacağını düşünen bir diğer katılımcı Can ise düşüncelerini “...zorlanırız çünkü alt yapısı olmayan bir sistem şu anda yeni gelişiyor ilk başta zorlanabiliriz...sadece bizle de bitmiyor okul yönetiminin katkısının olması 
lazım...önümüzde sınavlar oldŭ̆u için öğrencilere hep ezbere bilgi verilmek zorunda kalıyor STEM uygulamalarını veliler istemeyebilir..." şeklinde ifade etmiştir.

Hem işini zorlaştırıp hem de kolaylaştıracağını düşünen Ata ise düşüncelerini “...STEM uygulamalarında kullanılması gereken materyaller var ülkemizin birçok yerlerinde bu materyalleri bulmak hiç de kolay değil fakat malzemeleri bulursak öğrencilerimin soyut işlemleri somutlaştırmasında ve onlara aktarabileceğim şeyleri direkt aktardığımda yarar sağlar..." şeklinde ifade etmiştir.

Tablo 3. "Meslek hayatınıza başladığınızda STEM uygulamaları ile ders işlemek motivasyonunuzu nasıl etkiler?" sorusuna ilişkin katılımcı görüşleri

\begin{tabular}{lll}
\hline \multicolumn{2}{l}{ Kategori: Motivasyona etkisi } & \multicolumn{1}{c}{ Kod } \\
\hline Katılımc1 & Artırır & \\
\hline Nur & Öğrenci ilgisi & \\
Ela & Aktiflik, Değişen teknoloji, Pratiğe yönelik & \\
Ece & Öğrenci ilgisi & \\
Oya & Öğrenci ilgisi, Aktiflik & \\
Efe & Öğrenci ilgisi & \\
Can & Aktiflik \\
Ata & Öğrenci ilgisi & \\
Ali & Öğrenci ilgisi & \\
Alp & Öğrenci ilgisi & \\
\hline
\end{tabular}

Tablo 8 incelendiğinde bütün katılımcıların STEM uygulamaları ile ders işlemelerinin motivasyonlarını artıracağı yönündedir. Katılımcılardan Nur, Ece, Oya, Efe, Ata, Ali ve Alp öğrenci ilgisinin ya da öğrenci başarısının motivasyonlarını artıracağını belirtmiştir. Katılımcılardan Ata düşüncelerini “...motivasyonumu kesinlikle artırır çünkü öğrencilerimin daha fazla gelişmesi için ve bugüne kadar kullanılan modellerin çok ileriye götürmediği için STEM uygulamasılyla öğrencilerin gelişim göstermesi bana büyük bir motivasyon sağlar. Öğrencilerimin başarı ve ilgisi artarsa benim de motivasyonumu artırır..." şeklinde ifade ederken Ali ise aynı konuda "...süreç içerisinde başarı yükseleceği için motivasyonumun yükseleceğini düşünüyorum. Çünkü onların başarısı benim yaptığım rehberlik çerçevesinde ilerleyeceğini düşünüyorum..." düşüncelerini belirtmiştir.

Diğer katılımcılardan Ela ise düşüncelerini “...motivasyonumu artırır...çünkü ezbere teoriye yönelik olsa sıkılırdım ama bu şekilde olduğu için teknolojide sürekli değiştiği için bende kendimi geliştirirdim... aktif olurum bir öğretmen ne kadar aktif olursa o kadar iyidir..." şeklinde ifade ederken diğer katılımcılardan Nur ise konu hakkında düşüncelerini “..öğrencileri istediğim seviyeye getirirsem zaten onların başarıların gördükçe motivasyonum artacaktır... öğrencilerde iyi etkilerini göreceğimdir. Inn gördükçe de 
motivasyonum daha çok artacak daha fazlasını yapmak isteyeceğim belki yine kendimi geliştirmek isteyeceğim..." şeklinde ifade etmiştir.

Katılımcılardan Can'ın düşünceleri ise “...aktif olmamız lazım aktif olursam derste motivasyonum artar..." şeklinde belirtken Oya ise düşüncelerini “...̈̈̆rencilerin öğrendiklerini gördükçe yani teorikte ezberliyorlar ama STEM kullanarak öğretirsek daha faydalı olur ve kalıcı bilgi elde etmiş oluruz bu benim motivasyonumu artırır..." şeklinde ifade etmiştir.

Tablo 4. "STEM uygulamalarının hangi fen derslerine daha uygun olduğunu düşünüyorsunuz?" sorusuna İlişkin Katılıma Görüşleri

\begin{tabular}{lllllllllll}
\hline Kategori & Kod & Nur & Ela & Ece & Oya & Efe & Can & Ata & Ali & Alp \\
\hline & Fizik & & $*$ & $*$ & $*$ & $*$ & $*$ & $*$ & $*$ & $*$ \\
& Kimya & & & $*$ & & $*$ & & $*$ & $*$ & \\
Uygun Dersler & Bütün & $*$ & & & & & & & & \\
& Alanlar & & & & & & & & & \\
& Yer ve çevre & & & & & & & & & \\
& bilimi & & & & & & & & & \\
& Biyoloji & & & $*$ & & & & $*$ & & $*$ \\
\hline Uygun Olmayan & & & & & & & & & & \\
\hline
\end{tabular}

Tablo 9 incelendiğinde Nur haricinde bütün katılımciların tamamı STEM uygulamalarının fizik dersine daha uygun olduğunu düşünmektedir. Ece düşüncelerini “...tabi ki akla ilk başta fizik geliyor. Çünkü daha uygulanabilir konular çok fazla nu biyolojide biraz daha az kimyada ise bir sürü deneyler var ama biyoloji diğerlerine göre STEM çok uygun değil gibi..." şeklinde ifade ederken katılımcllardan Ata ise düşüncelerini "...STEM uygulamaları daha çok biyoloji değil de fizik ve kimyaya daha uygun olduğunu düşünüyorum. Çünkü onlarn daha deneysel ve pratiğe dökülebilir olduğunu düşünüyorum. Biyolojinin ise daha çok teorik olduğunu düşündüğ̈̈m için orada uygulamaz biraz daha zor olabilir..." cümleleriyle ifade etmiştir.

STEM uygulamalarının bütün alanlara uygun olduğunu düşünen Nur ise düşüncelerini “...bence her alana aşă̆ı yukarı uygulanabilir. Çünkü STEM adı üzerinde içerisinde bilim var biyoloji konularına da çok rahatlıkla uygulanabilir sonuçta mitoz bölünmeyi mühendislik var sonuçta hem de bilimle ortaya koyabilir matematikle ölçüm yaparak mühendislikte de bir şeyler tasarlayabilir yani her konuya uygulayabiliriz..." şeklinde ifade etmiştir.

STEM uygulamalarının yer bilimi ve çevre bilimi ile ilişkili olduğunu düşünen Ali ise konu hakkındaki düşüncelerini "...En çok yer ve çevre bilimi diyebilirim. Çünkü iki dersin temasında doğa. Öğrenci gördü̆̆̈̈nü doğasında karşılaştırabilir. Diğeri ise fizik diyebiliriz. Fizik dersinde öğrenci bilgiyi aldı̆̆ı zaman kendi süzgecinde geçirip doğayla ilişkilendirmesi lazım diyebiliriz..." şeklinde ifade etmiştir. 
Tablo 5. "STEM uygulamaların ilköğretim fen konuları dikkate alındığında hangisine uyarlardın? Nasıl?" sorusuna ilişkin katılımoı görüşleri

\begin{tabular}{|c|c|c|c|c|c|c|c|c|c|c|}
\hline Kategori & Kod & Nur & Ela & Ece & Oya & Efe & Can & Ata & Ali & Alp \\
\hline \multirow{6}{*}{ Fen Konuları } & Basit makineler & * & & * & & & $*$ & & $*$ & * \\
\hline & Basınç & & & & & & & * & * & \\
\hline & Hiz & & * & & & & & & & \\
\hline & Asit ve baz & & & & $*$ & & & & & \\
\hline & $\begin{array}{l}\text { Destek ve } \\
\text { hareket sistemi }\end{array}$ & & & & & * & & & & \\
\hline & Kuvvet & & & & & & * & & & \\
\hline
\end{tabular}

Tablo 10 incelediğinde katılımcılardan Nur, Ece, Can, Ali ve Alp STEM uygulamalarını ilköğretim fen konularında basit makinelere uyarlayacağını belirtmiştir. Diğer katılımcılar ise farklı fen konuları üzerine görüşlerini belirtmiştir. Basit makinelere uyarlarım diyen Nur düşüncelerini “...Basit makineleri mesela uygulayabilirim...orada makaralarm nasıl bir özelliğe sahip olduğunu fen konusundan ve bunu tasarlarken teknolojiden yararlanıyor mühendislik bilgisi de devreye giriyor şunu şuraya yaparsam böyle olur diye ölçümde devreye girdiği için matematikte işin içerisinde yani genel olarak bu şekilde..." şeklinde ifade etmiştir.

Diğer katılımclardan Ata ise düşüncelerini “...basınç konusunu seçerdim. Bilim konusunda öncelikle bilimin tarihinden başlardım mesela Pascal basıncının hangi süreçlerden geçirildiğine nasıl geliştiğini bilimsel bilginin nasıl değiştiğini anlatırdım. Teknoloji konusunda ise basıncın günlük hayatımızda sanayide nerede kullanıldığını, mühendislik konusunda ise basınç kullanılarak ne geliştirilebilir ya da mühendisler hangi alana yöneliyor günümüz teknolojisi bu yönde hangi alana yöneliyor onu gösterirdi. Matematik alanında ise basıncın daha anlaşılabilir hale gelebilmesi için matematiğin neden gerekli olduğunu aktarmaya çalışırdım..." şeklinde ifade etmiştir.

Diğer katılımcılardan Ela ise hız konusuna uyarlayacağını belirtirken düşüncelerini "hız konusunu mesela yine robottan örnek vereceğim robot yaptı̆̆ımızda bilgisayardan kodlama şeklinde arabanın hızın ayarlayabiliyorsun. Bir arabanın hızın yavaş ayarlarsın bir arabanın hızını az ayarlarsın oradan da mesafeleri ölçümünü yaparsın matematikte oradan..." şeklinde ifade etmiştir.

Katılımclardan Oya asit ve baz konusuna uyarlayacağını belirtmiş ve düşüncelerini “... kimya asit baz deneyleri olabilir. Mesela karnabahar suyunu çıkarıp orda deneyler yapmıştı bizim hocamız aklımda kaldı biz sunularda da yaptık iyiydi yani etkili oluyor yani o değişimi görmeleri çok güzel mesela deterjan falan yine öyle şeyler katarak içerisine renk değişimlerini gözlemleyebiliyorlar..." cümleleriyle ifade etmiştir. 
Katılımclardan Efe ise destek ve hareket sistemi konusundan yararlanarak robot tasarlayacağını belirtmiştir ve düşüncelerini “... destek ve hareket sisteminden yola çıkarak bir robot tasarlayabilirdim yani zaten önümde bir taslak duruyordur ondan yola çıkarak hayvan olabilir insan olabilir bir robot tarzı ya da işimizi kolaylaştıracak alet tasarlamak istediğim zaman ondaki mühendislikten faydalanabilirdim...zuplayan bir robot tasarlamak istediğim zaman çekirgeden çekirgenin ayaklarından faydalanabilirdim ve bu fen tarafi olurdu buna bakıp da yapacağım materyalleri seçmem ve tasarımı sağlaman mühendislik tarafı olurdu. Bu hesaplamaları yapıp da robotun ne kadar uzun süre şarj edileceğ $i$, dayanabileceği ya da ne kadar yük taşıyabileceğini hesaplamamda matematik kısmın ilgilendirirdi ve bunu hayata geçirdiğim zamanda teknoloji boyutu olurdu..." şeklinde ifade etmiştir.

Diğer katılımcılardan Can ise kuvvet konusuna uyarlayacağını belirtirken düşüncelerini “...kuvvet olabilirdi mesela...Kuvveti bulmak için bilim gereklidir. Teknoloji kısmı ise kuvvetten yararlanıp birçok icat yapılabilir ya da yapılmıştır bunlardan birine roketler falan diyebiliriz mesela en başta dediğim mancınık kuvvetin etkisiyle bulunmuş bir icat teknoloji bence bu taraftı. Mühendislik bence bunun biraz tasarım kısmında olabilir. Matematikte ise hangi açıla gitmesi gerekiyor nasıl bir kuvvet uygulamamız gerekiyor kısmında da matematik ilgileniyor diyebiliriz..." şeklinde ifade etmiştir.

Tablo 6. "Öğretmen açısından fen bilimleri derslerinde STEM uygulamaları kullanmanın avantajları ve dezavantajları nelerdir?" sorusuna ilişkin katılıma görüşleri

\begin{tabular}{|c|c|c|c|c|c|c|c|c|c|c|}
\hline Kategori & Kod & Nur & Ela & Ece & Oya & Efe & Can & Ata & Ali & Alp \\
\hline \multirow{9}{*}{$\begin{array}{l}\text { Uygulamaların } \\
\text { olumlu ve } \\
\text { olumsuz yanları }\end{array}$} & Somut anlatım & & & * & & & & * & & * \\
\hline & $\begin{array}{l}\text { Eleştirel } \\
\text { düşünme }\end{array}$ & * & & & & & * & & * & \\
\hline & Kalıcı bilgi & & & & * & * & & & & \\
\hline & $\begin{array}{l}\text { Problem çözme } \\
\text { becerisi }\end{array}$ & * & * & & & & & & & \\
\hline & Yaratıcılık & & * & & & & & & * & \\
\hline & Motivasyon & & & & * & & & & & \\
\hline & Maliyet & & & * & * & * & * & * & & * \\
\hline & Yorar & & & & * & * & & & * & \\
\hline & Bilgi eksikliği & & * & & & & & & & \\
\hline
\end{tabular}

Tablo 11 incelediğinde katılımcıların STEM uygulamalarının öğretmen açısından birçok avantajlarının ve dezavantajlarının olduğunu belirttikleri görülmüştür. STEM uygulamalarının avantajlı yönlerinin somut bir anlatım ve eleştirel düşünme becerisi olduğunu belirten katılımcı sayısı diğerlerine göre fazladır. Dezavantajları konusunda ise STEM uygulamalarının maliyet açısından sıkıntı olduğunu belirten katılımcı sayısının diğerlerine göre fazla olduğu görülmektedir. 
Katılımcılardan Ata avantajlarını belirtirken düşüncelerini “...̈̈ğrencilere anlatmak istediği konularda daha çok somutlayarak etkin katılımını daha çok sağlar..." şeklinde ifade ederken dezavantajları konusunda ise "...para, maddi yönden de sıkıntılar çıkabilir..." düşünceleriyle ifade etmiştir.

Diğer katılımcılardan Can ise avantaları konusunda düşüncelerini “...öğretmen ilk başta kendini düşünür bu düşünme becerisini kazanmak çok önemli bunu da STEM sayesinde kazanabiliriz...yaratıcılı̆̆ımız gelişebilir çünkü farklı ürünler ortaya koyabiliriz düşüncemiz gelişir bunlarda avantajlarımız olabilir..." şeklinde ifade ederken dezavantajları konusunda ise düşüncelerini “...maliyet konusunda olabilir yani ödenek bulamıyoruz MEB okullara ödenek sağlaması gerekiyor..." cümleleriyle ifade etmiştir.

Katılımcılardan Oya ise “...kalıcı bilgi sağlar...öğretmeni motive eder öğrenciler öğrenirlerse bu öğretmeni mutlu eder öğretmenin de şevkini artırır..." avantajlarını ifade ederken, dezavantajları konusunda ise “...̈̈ğretmeni yorar, öğrencileri toplamak ve sınıf yönetimi açısından yorar diye düşünüyorum bir de maliyet açısından problem olabilir getireceği malzemelerden dolayı..." düşüncelerini ifade etmiştir.

Diğer katılımcılardan Ela ise düşüncelerini “...öğretmen kendini sürekli yenilemek geliştirmek zorunda kalır, problem çözme becerisi gelişir...21. Yy. teknoloji zamanındayız STEM de teknolojidir ve çă̆a ayak uydurur..." şeklinde ifade ederken dezavantajları konusunda "...bilgi eksikliği elbette kalır bu yüzden dezavantaj olacă̆ını düşünüyorum..." düşüncelerini ifade etmiştir.

Bir diğer katılımcı Alp ise avantajları hakkında düşünceleri “...avantajları şu çocukların zihinlerinde daha somut bir yaklaşımla yaklaşırsanız onların daha iyi öğrenmelerini sağlayacaktır..." şeklinde ifade ederken dezavantajları hakkındaki düşüncelerini "...alt yapr henüz uygun değil maddiyat uygun değil bizim ülkemizde bir de hani yetişmiş eleman gücü falan diyor ya daha biz de bunlar görmedik onun için dezavantaj oluşturabilir..." şeklinde ifade etmiştir. 
Tablo 7. "Öğrenci açısından fen bilimleri derslerinde STEM uygulamaları kullanmanın avantajları nelerdir?" sorusuna ilişkin katılımo görüşleri

\begin{tabular}{|c|c|c|c|c|c|c|c|c|c|c|}
\hline Kategori & Kod & Nur & Ela & Ece & Oya & Efe & Can & Ata & Ali & Alp \\
\hline \multirow{7}{*}{$\begin{array}{l}\text { Uygulamaların } \\
\text { olumlu yanları }\end{array}$} & Kalıcı bilgi & * & & & * & * & * & & * & \multirow{7}{*}{ * } \\
\hline & Yaratıcilık & * & $*$ & & & * & * & $*$ & & \\
\hline & $\begin{array}{l}\text { Problem } \\
\text { çözme } \\
\text { becerisi }\end{array}$ & * & * & & & & * & * & & \\
\hline & $\begin{array}{l}\text { Psikomotor } \\
\text { beceri }\end{array}$ & * & & * & & & & & & \\
\hline & $\begin{array}{l}\text { Eleştirel } \\
\text { düşünme }\end{array}$ & & \multirow[t]{3}{*}{$*$} & & & \multirow[t]{3}{*}{$*$} & & \multirow[t]{3}{*}{ * } & & \\
\hline & $\begin{array}{l}\text { 21. Yy. } \\
\text { becerisi }\end{array}$ & * & & * & & & & & & \\
\hline & Girişimcilik & & & * & & & & & & \\
\hline
\end{tabular}

Tablo 12 incelendiğinde öğrenci açısından fen bilimleri derslerinde STEM uygulamalarının kullanılması öğrencilerde kalıcı bilginin oluşmasına ve yaratıcılık duygusunun gelişmesine katkısının olduğunu belirten katılımcı sayısı diğerlerine göre fazladır. Örneğin katılımcılardan Efe öğrencilerin kalıcı bilgilerinin ve yaratıcılığının artacağı için avantaj sağladığını düşünmektedir. Bu konu hakkındaki düşüncelerini “...konuların anlaşılmasını artırır, bunları tasarlarken eleştirel düşünme ve yaratıcı düşünme basamaklarına çıkarak zihinsel gelişim artar. Yaratıcı basamaktan destek alarak kas ve el becerileri gelişir. Üretkenliğini artırır..." şeklinde ifade etmiştir.

Diğer katılımcılardan Nur ise düşüncelerini “...psikomotor beceri kazandıracak hayatta karşılaştığı problemlere karşı çözüm becerisi kazandıracak hayata hazırlayacak yani hayatın ta kendisine hazırlayacak sonra yaratıcılık ortaya çıkacak ve 21. Yy. becerilerini kazanmış olacaktır..." şeklinde ifade ederken Ece ise düşüncelerini “...düşünme becerileri psikomotor beceriler olmak üzere birçok alandaki becerileri geliştirecek, özgüvenleri gelişecek girişimciliği artacak. Girişimcilik bence çok önemli..." cümleleriyle ifade etmiştir.

Katılımcilardan Ela ise konu hakkındaki düşüncelerini “...Meslek seçiminde avantaj olabilir problem çözme yeteneği artar eleştirel düşünme yeteneği artar yaratıcılık yeteneği artar teorikten çok kendileri bir şeyler üretmeye heveslenir mesela bir eğitimi aldı̆̆ zaman o eğitimi üretmek için şu an zaten doğan çocuklar bile telefonlar sürekli ellerinde onlara

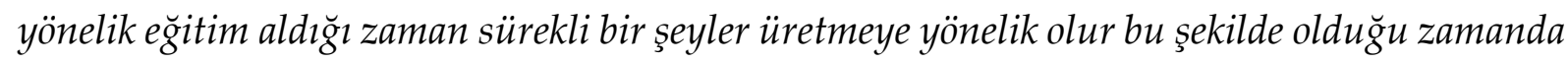
da mesela biz yurt dışından telefonlar kullanmayız da kendi ürettiğimiz telefonları kullanırız..." şeklinde ifade etmiştir. 
Tablo 8. "STEM eğitiminin öğretmenlik kariyerinize ne gibi katkılarının olacağını düşünüyorsunuz?" sorusuna ilişkin katılımcı görüşleri

\begin{tabular}{lllllllllll}
\hline Kategori & Kod & Nur & Ela & Ece & Oya & Efe & Can & Ata & Ali & Alp \\
\hline & $\begin{array}{l}\text { Maddi ve } \\
\text { manevi kazanç }\end{array}$ & $*$ & $*$ & & $*$ & & $*$ & $*$ & & \\
Mesleğe & $\begin{array}{l}\text { Akademik } \\
\text { kariyer }\end{array}$ & $*$ & & $*$ & & & & $*$ & & \\
Katkıları & & & & & & & & & \\
& Kalıcı öğrenme & & & & $*$ & & & & $*$ \\
& Araştırma ruhu & & & & & & & & & \\
& & & & & & & & & \\
\hline
\end{tabular}

Tablo 13 incelendiğinde STEM eğitimlerinin katılımcılara birçok katkısının olacağı belirtilmiştir. Bu katkılardan maddi ve manevi kazancının olacağını belirten katılımcı sayısı diğerlerine göre fazla olduğu görülmektedir. Örneğin, katılımcılardan Nur STEM'in maddi ve manevi anlamda kazanç sağlayacağı yönündeki düşüncesini “...yüksek lisans yapabilirim böyle bir kariyer sağlayabilir bana...STEM yeni bir şey olduğu için bu konuda kurs falan açabilirim ilerleyen zamanlarda..." şeklinde ifade ederken, Ela ise "...ilerleyen yıllarda atandığım okulda kurs açabilirim, kurs açtığım zaman gelecek nesilleri o şekilde eğitebilirim, alt yapıyı verebilirim ve daha sonrasında zaten onlar üzerine bir şeyler koyar üretim yapma aşamasına gelebiliriz..." cümleleriyle ifade etmiştir. Aynı konu üzerine Oya ise düşüncelerini “...sevilen öğretmen oluruz, yenilik yapan öğretmen oluruz bu da bana manevi bir kazanç să̆lar..." şeklinde ifade etmiştir.

Katılımcılardan Alp ise düşüncelerini “...STEM eğitimi bilen biri öğrencisinin kafasında daha fazla şeyler oluşturabilir. Hayal gücünü yükseltir, bilgileri daha fazla somutlaştırabilir daha iyi anlatabilir. Kalıcı öğrenmeler gerçekleşir..." şeklinde ifade etmiştir.

Diğer katılımcılardan Ali ise düşüncelerini “...öğrencilerimize araştırma ruhunu aşılarken bende araştırma ruhuna sahip olacağımı düşünüyorum..." cümleleriyle ifade etmiştir. 
Tablo 9. "STEM uygulamalarının artması için nasıl çalışmalar yapılmalıdır?" sorusuna ilişkin katılımcı görüşleri

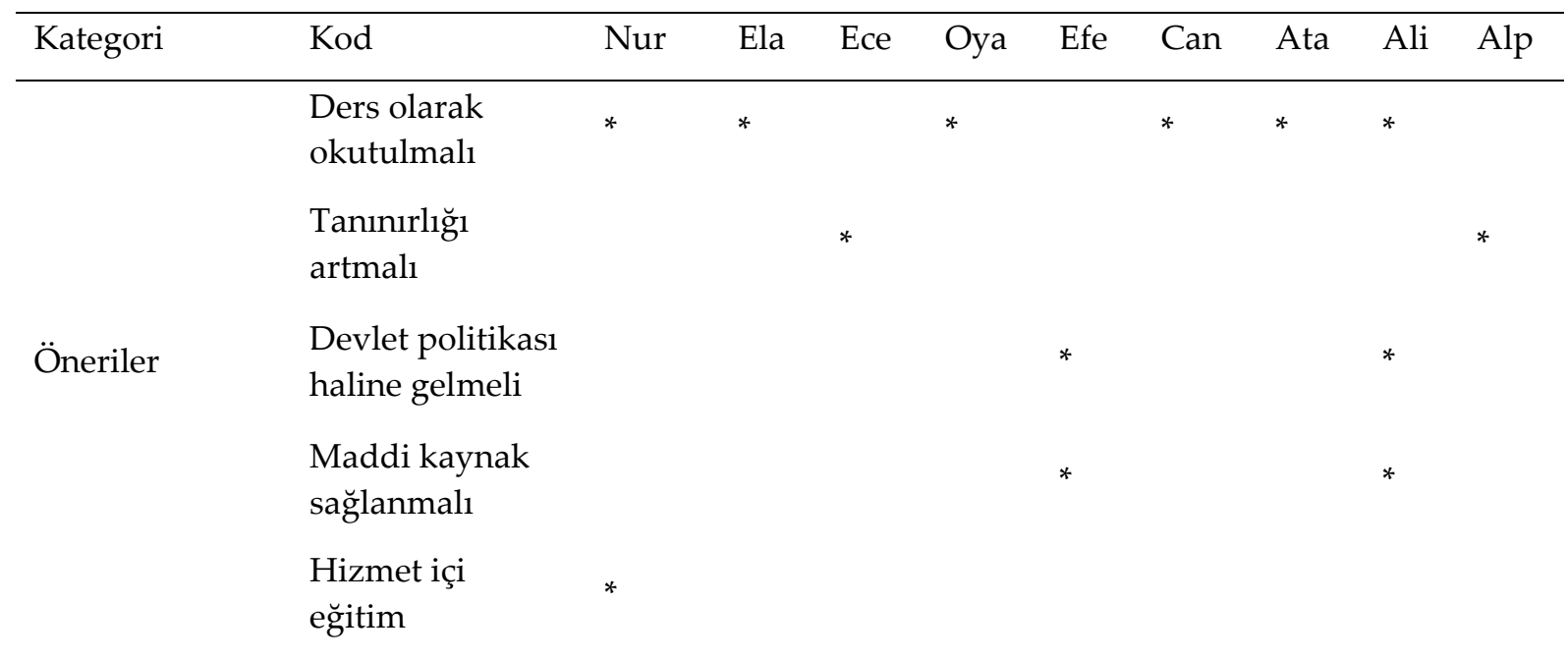

Tablo 14 incelendiğinde STEM uygulamalarının artması bir yöntem veya yaklaşım olmaktan daha fazla ders olarak okutulması gerektiği belirten katılımcı sayısı diğerlerine göre fazladır. Katılımcılardan Oya ders olarak okutulması gerektiğini belirterek düşüncelerini “...bizim eğitim fakültelerinde bir konuyu nasıl anlatmamız gerektiği hangi teknikleri kullanacağız onlara öğrenmeliyiz. Buradan STEM'i de yedirirsek derslerimize yani üniversitede yerleştirirsek bizde öğrencilerimize daha iyi eğitim veririz ve onlarda daha güzel bir nesil getirirler bize..." şeklinde ifade ederken Ata ise düşüncelerini "...okullarda ders olarak okutulmalı çünkü STEM uygulamaların uygulayacak öğretmenler yetiştiremediğimizde zaten öğretmenler sistemi uygulayamıyor, öncelikle zorunlu bir ders haline gelmeli hatta lisede bile öğrencilere bu konuda bilgiler verilmeli ki üniversitede de verilmeli zaten..." şeklinde ifade etmiştir.

Diğer katılımcılardan Ali ise düşüncelerini “...öncelikle eğitim fakültelerinde STEM ile ilgili bir dersin verilmesi lazım...MEB'in hedefinde biraz daha STEM'e daha çok yoğunluk verebilmesi lazım. Bununla ilgili ödeneklerin olması lazım çünkü STEM dediğin zaman fen bilgisinin genel konuları laboratuvar ile ilgili yap model üret sürekli bunlarla ilgili $M E B^{\prime}$ in biraz daha bütçe ayırması lazım diye düşünüyorum..." cümleleriyle ifade etmiştir.

Katılımcılardan Efe düşüncelerini “...en temelden başlayarak hükümet planlarında devlet politikalarında destek verilmesini isterim...maddi kaynaklarında ayrılması isterim..." şeklinde ifade etmiştir. Diğer katılımcılardan Nur ise düşünceleri “...STEM konusunda hizmet içi eğitimlerin hat safhaya çıkarılması gerekli bence..." cümlesiyle ifade etmiştir.

\section{Sonuç ve Tartışma}

Bu kısımda fen bilgisi öğretmen adayları ile gerçekleştirilen yarı yapılandırılmış görüşme kayıtlarının analizi sonucunda, STEM uygulamalarına yönelik görüşlerden elde edilen sonuçlar kategoriler halinde ayrı ayrı incelenmiş, alan yazındaki mevcut diğer çalışmalarla karşılaştırılarak tartışılmıştır. 
Fen bilgisi öğretmen adaylarının fen bilimlerini birçok disiplinlerle ilişkilendirdikleri sonucuna varılmıştır. Eroğlu ve Bektaş (2016) fen bilgisi öğretmenleri ile yapılan çalışma sonucunda katılımcılar fen bilgisi alanını diğer disiplinler ile ilişki içerisinde olduğunu, bunun sonucunda ise fen bilimleri dersinin bölümler arası bir yaklaşıma sahip olduğunu saptamışlardır. Ayrıca Erduran (2013) fen bilimlerini anlamanın tek yönünün olmadığını, farklı yönlere sahip bir olgu olduğunu sonucuna varmıştır. Bu sonuçlar çalışmanın disiplinler kategorisi ile ilgili sonucunu destekler niteliktedir. Buradan hareketle, fen bilgisi öğretmen adayları fen bilimlerini sadece fizik, kimya ve biyoloji ile kalmayıp sosyal bilimler, doğa bilimleri gibi birçok disiplinle ilişkilendirmektedirler. Dolayısıyla, fen bilgisi öğretmen adaylarının daha anlamlı bir fen bilgisi eğitimi ve öğretimi yapabilmeleri için fen biliminin birçok disiplinle ilişkilendirilmesi ve bu adaylarında bu ilişkilendirme dikkate alınarak yetiştirilmesi gerekmektedir.

Öğretmen adaylarının STEM kavramını tanımladıklarını ve STEM kavramına yönelik örnekler verdiği sonucuna varılmıştır. STEM kavramını tanımlarken en az iki alanı ilişkilendirdikleri görülmektedir. Dolayısıyla öğretmen adaylarının birçok disiplini bir araya getirerek bütüncül STEM eğitimi kavramını ortaya çıkardığı düşünülebilir. Thomas (2014) yapmış olduğu çalışmada STEM fen, mühendislik, matematik ve teknoloji disiplinleri arasında bağlantı sağlamaları gerektiğini ifade etmektedir. Bu sonuç çalışmamızın STEM tanımı kategorisini destekler niteliktedir. Dolayısıyla öğretmen adaylarının STEM'in doğasına ilişkin düşünceleri STEM uygulamalarını kullanarak daha belirgin hale gelmesi gerekmektedir. Burada bir diğer nokta ise STEM'in tanımını bilmek demek gerçekten de STEM'i etkili bir şekilde uygulayabilmek midir? Bir başka ifadeyle, öğretmen adaylarının STEM'in tanımını duyduklarından veya okuduklarından yola çıkarak tanımlayabilmesi onların gelecekte iyi bir STEM uygulayıcısı olacağı anlamına gelmez. Dolayısıyla, STEM uygulamalarında öğretmen adaylarının taksonomi açısından düşük düzeyde yer alan kazanımları kazanmaları yerine daha çok uygulamaya yer vermek, onların STEM'i daha etkili uygulayacakları anlamına gelebilir.

Fen bilgisi öğretmen adaylarının eğitim fakültesinde gördükleri derslerin STEM uygulamaları ile entegre edilmesi gerektiği sonucuna ulaşılmıştır. STEM uygulamaları ile derslerinde teorik bilgiden çok daha pratik bilgilerle kalıcı öğrenmelerin gerçekleşeceğini düşündükleri sonucuna ulaşılmıştır. Yıldırım ve Altun (2015) tarafından fen bilgisi öğretmen adayları ile STEM uygulamalarının derslere entegrasyonu ile ilgili yürütülen çalışmada STEM eğitimi ve mühendislik uygulamalarının öğrencilerin ilgilerini ve başarılarını artırmada etkili olduğu sonucuna varılmaktadır. Bu çalışma fakülte derslerinde STEM'in uygulanması kategorimizi destekler niteliktedir. Dolayısıyla eğitim fakültelerinde verilen derslerde STEM uygulamaları ile entegre edildiğinde daha donanımlı daha bilgili öğretmenlerin gelecek nesilleri çağın gerektirdiği gibi yetiştirme imkânı artacaktır. STEM uygulamalarını derslerine entegre etme konusunda öğretim görevlilerine büyük iş 
düşmektedir. Eğitim fakültelerinde özellikle materyal tasarımı ve özel öğretim yöntemleri gibi derslerde STEM uygulamalarına ağırlık verilmelidir.

Öğretmen adaylarının fen bilgisi alan eğitimi derslerine ilaveten STEM uygulamaları isimli bir dersin öğretim programına konulması gerektiği sonucuna ulaşılmıştır. Öğretmen adayları yeni çağın öğretmenleri olacakları için STEM uygulamalarını farklı derslerin içerisinde öğrenmek yerine daha ayrıntılı bir şekilde öğrenmek istedikleri görülmüştür. Eğitim fakültelerinde öğretmen adaylarının STEM uygulamaları hakkında bilgilerini ve becerilerini artırmak için fen fakültesi ve mühendislik fakülteleriyle ortak çalışmalar düzenlenmelidir (Tezel ve Yaman, 2017). Nasıl ki bilimin doğası dersinde bilimin doğuşunu, bilim tarihini, bilim insanlarının araştırmalarını ayrıntılı bir şekilde öğretip öğretmen adaylarını bilimi aşılamaya çalışıyorsak aynı şekilde STEM uygulamaları eğitimin yöntemini de ayrı bir ders olarak verip STEM' in bazı derslerde kısa bir şekilde anlamak yerine STEM'in doğuşu, STEM'in tarihini, STEM hakkında geçmişte yapılan çalışmalardan günümüzde yapılan çalışmalara kadar ayrıntılı ve derinlemesine bilgileri öğretmen adaylarına öğretip STEM ruhunu aşılayabiliriz. Öğretmen adaylarının bu düşünceleri neticesinde eğitim fakülteleri ve YÖK iş birliği sayesinde fen bilgisi öğretmenliği öğretim programına STEM uygulamaları dersinin ilave edilmesi gerekmektedir. Yukarıda STEM uygulamalarının bazı derslere entegre edilmesinden bahsedilmişti, hatta STEM uygulamalarının ayrı bir ders olarak yürütülmesi 21. yüzyıl becerilerinin öğretmen adaylarına daha etkili kazandırılması açısından oldukça önemlidir.

Daha önce STEM eğitimleri katılmayan öğretmen adaylarının STEM eğitimi aldıklarında kendilerini daha fazla geliştireceklerini ve tecrübe sahibi olacakları sonucuna varılmıştır. Gelecekteki fen eğitimi açısından düşündüğümüzde STEM uygulamaları hakkında olumlu düşünceye sahip olan öğretmen adaylarının görüşleri oldukça önem arz etmektedir. Ayrıca öğretmen adaylarının STEM eğitimleri sayesinde eleştirel düşünme, yaratıcı düşünme gibi birçok 21. yüzyıl becerilerini kazanıp daha donanımlı birer öğretmen olacakları sonucuna varılmıştır. Aygen (2018) yapmış olduğu yüksek lisans tez çalışmasında STEM eğitimini düzenli ve kusursuz şekilde alan öğretmen adaylarının meslek yaşantılarında öğrencilerine bu eğitim sebebiyle yeniliklere karşı takipte olan, yaratıcı becerisi yüksek olan bireylerin yetişmesine katkı sağlayabilir. Başka bir çalışmada ise STEM eğitiminin kalıcı öğrenmeler sağladığı, motive edici ve eğlenceli olduğu sonucuna varılmıştır (Bozkurt Altan, Yamak ve Buluş Kırıkkaya, 2016). Yapılan bu çalışmalar sonucu STEM eğitimi kategorimizi destekler niteliktedir. Dolayısıyla STEM eğitimleri öğretmen adaylarının donanımlarını artmada büyük katkı sağlayacaktır. Öğretmen adayları için planlanan STEM eğitimleri sayısı artırılmalı ve bu eğitimler öğretmen adaylarına katkı sağlayacak şekilde düzenlenmelidir. Bu sayede öğretmenlerin STEM uygulamaları konusunda tecrübe kazanmaları sağlanabilir. Bu sayede birçok öğretmen TUBİTAK vb. kuruluşlarının yapmış oldukları yarışmalara öğrencilerine hazırlayıp daha üretken bir nesil yetişmelerini sağlanabilir. 
STEM uygulamalarının öğretmen adaylarının meslek hayatlarında imkanların iyi olduğu, gerekli alt yapı ve materyallerin sağlandığı durumlarda işlerini kolaylaştıracağı sonucuna ulaşılmıştır. Belirtilen durumların sağlanması durumunda STEM uygulamalarının olumlu özellikleri konuların daha görsel şekilde belirtilmesi, öğrenci merkezli yöntemler kullanılması bu sayede kalıcı öğrenmelerin gerçekleşmesi ve soyuttan somuta şeklinde sıralanabilir. Alan yazın incelendiğinde Siew, Amir ve Chong (2015) yılında yapmış oldukları çalışmalarında bu çalışmanın sonuçlarıyla benzer olarak öğretmenlerin süre, materyal ve alan bilgisinin yeterli düzeyde olmaması gibi çeşitli zorlukları ifade ettikleri görülmektedir. Aynı şekilde Hacıoğlu, Yamak ve Kavak (2017) fen bilgisi öğretmen adaylarıyla yapmış oldukları çalışmada STEM uygulamalarını öğretmen olduklarında kullanmak istediklerini fakat uygulama esnasında yeterli düzeyde olmadıkları düşüncesiyle tereddütlü ve kaygılı cevaplar verdiklerini belirtmişlerdir. Bu çalışmalar meslek hayatıma etkisi kategorisini destekler niteliktedir. Bu yüzden öğretmen adaylarının STEM uygulamaları ile ilgili eğitim fakültelerinde pratik uygulamalar yapılarak tecrübe kazanmaları sağlanmalıdır. Eğitim fakültelerinde özellikle fizik laboratuvarı, kimya laboratuvarı, biyoloji laboratuvarı ve fen öğretimi laboratuvar uygulamaları gibi derslerde STEM uygulamalarına ağırlık verilmelidir.

STEM uygulamalarının öğrencilerin fen bilimleri dersine karşı ilgi ve istediklerini artırdıklarını ve bu gayret ve çabanın neticesinde öğretmenlerde kendilerini daha mutlu hissedeceklerini sonucuna ulaşılmıştır. Ayrıca STEM uygulamaları ile dersini işleyen öğretmenler derslerinde daha aktif oldukları için motivasyonlarının arttığı sonucuna ulaşılmıştır. Alan yazın incelediğinde Güneş ve Taştan Akdağ (2017) yapmış oldukları çalışmada fen lisesi öğrencilerine STEM uygulamaları ile enerji konusu anlatılmış, daha sonra öğrenci ve öğretmenlerin görüşleri alınmıştır. Çalışma sonucunda STEM uygulamalarının bilginin kalıcılığını, öğrenilen bilgilerin günlük hayata karşılaşılan problemlerde kullanıldığını, öğrenci ve öğretmenlerin motivasyonlarını artırıcı yönde etkisini tespit etmişlerdir. Başka bir çalışmada ise Jesus ve Lens (2005) öğretmenlerin motivasyonlarının öğrenci motivasyonlarını etkilediğini ve motive olmuş öğretmenlerin eğitimdeki reformların gerçekleşmesindeki istekliliği ile garanti sağlayan en önemli unsurlar olduğunu belirtmektedir. Alan yazındaki benzer araştırmaların sonuçları, STEM uygulamalarının öğretmen ve öğrenci başarılarını artırdığı bu sayede öğretmenlerin motivasyonlarının arttığı sonucuna ulaşılan bu çalışmayı desteklemektedir. $\mathrm{Bu}$ bağlamda, STEM uygulamalarının okullarımızda reform hareketine dönüşebilmesini sağlamak için öğretmen ve öğretmen adaylarının STEM etkinliklerini bilmeleri ve tecrübe etmeleri gerekmektedir.

Öğretmen adayları STEM uygulamalarının fizik ve kimya dersinin daha uygulanabilir yanının olduğunu, biyoloji dersinin ise genel olarak sözel ders olduğu için STEM uygulamalarının uygun olarak görmedikleri bu nedenle STEM uygulamalarının daha çok fizik ve kimya derslerine yakın gördüklerine sonucuna ulaşılmıştır. Eroğlu ve Bektaş (2016)'ın çalışmalarında ise öğretmenlerin STEM bazlı 
etkinlikleri fizik konularına uygun olarak gördükleri sonucuna ulaşılmıştır. Alan yazındaki bu çalışma sonucumuzu destekler niteliktedir. Oysaki bu alg1 doğruyu yansıtmamaktadır. Birçok disiplinlerle etkileşim içerisinde olan STEM istenilen alanda etkin bir şekilde kullanılabilir. Bu durumu kavram yanılgısını açıklamak için öğretmen adaylarına STEM' in doğası kavramının gerekli derslerde ayrıntılı bir şekilde verilmesi gerekmektedir.

Öğretmen adayları ile yapılan görüşmelerde tüm öğretmen adaylarının neredeyse ayn fen konusunu örnek verdikleri görülmüştür. Bilimi, teknoloji, mühendislik ve matematiği kullanarak fen konularından birine uyarlama yapan öğretmen adaylarının özellikle tasarım yapabileceği, mühendislik becerilerinin katkısının fazla olduğu konuları belirledikleri sonucuna ulaşılmıştır. Öğretmen adaylarının yaparak yaşayarak öğrenmeyi sağlaması ve sorgulamaya dayalı olmasını ifade etmiş mühendislik tasarım sürecinde bilimsel sorgulama olmaksızın deneme yanılma yöntemi ile değil sorgulama yöntemi ile yürütülmüş olması gerektiği olumlu bir durum olarak değerlendirilmiştir (Bozkurt Altan vd., 2016). Bu çalışmada da değerlendirildiği gibi öğretmen adaylarının sorgulayarak, yaparak yaşayarak bir şeyler üretme ve tasarlayacağı konulara yöneldiğini söyleyebiliriz. Oysaki STEM sadece tasarım boyutunda oluşmamaktadır. Bağımlı ve bağımsız değişkenlerle herhangi bir konu üzerinde yapilabilecek bir bilimsel problemi de STEM uygulamaların benimseyerek belirli bir çözüme kavuşturabiliriz.

Öğretmen adaylarının görüşleri sonucunda öğretmen açısından STEM uygulamalarının olumlu özelliklerinin yanında olumsuz özelliklerinin de olduğu sonucuna ulaşılmıştır. Bu özellikleri maliyet, daha fazla gayret gösterme neticesinde yorulma ve STEM hakkında bilgi eksikliği olarak sıralayabiliriz. Alan yazın incelendiğinde STEM uygulamalarının olumsuz özelliklerinin bulunduğu çalışmalar yer almaktadır (Eroğlu ve Bektaş, 2016; Siew vd., 2015;). Siew ve arkadaşları (2015) yapmış oldukları çalışmalarında, bu çalışma sonuçlarına paralel olarak, öğretmenlerin zaman, malzeme ve konu alanına hâkim olamama açılarından zorluklarla karşılaştıklarını tespit etmişlerdir. Diğer çalışmada ise Eroğlu ve Bektaş (2016) fen bilimleri öğretmenlerinin STEM temelli ders etkinliklerinin bir takım olumsuz yanlarının olduğunu düşündüklerini tespit edilmiştir. Öğretmenler zaman, malzeme sıkıntısı, amaç haline getirme ve konuya hâkim olma zorunluluğu gibi açılardan bazı olumsuzluklar dile getirmişlerdir. Yapılan bu çalışmalar öğretmen açısından uygulamaların olumlu ve olumsuz yanları kategorimizi destekler niteliktedir. Fakat Ensari (2017), yapmış olduğu yüksek lisans çalışmasında STEM etkinlikleri için materyal bulma konusunda öğretmen adaylarının genel olarak zorluk çekmediklerini gözlemlemiştir. Bu çalışma ile karşılaştıııldığında ise fen bilgisi öğretmen adaylarının STEM uygulamalarına ön yargı ile yaklaştıkları sonucuna ulaşılabilir. Oysaki elimizde bulunan materyallerle bile STEM uygulamalarını gerçekleştirebiliriz. Bir önceki sonuçlarda da denildiği öğretmen adaylarına oluşan kavram yanılgısını açıklamak için STEM'in doğası kavramının gerekli derslerde ayrıntılı bir şekilde verilmesi gerekmektedir. 
Öğretmen adayları STEM uygulamalarının öğrenci açısından kalıcı bilgiler sağladığı, yaratıcılık, problem çözme, eleştirel düşünme becerilerini geliştirdiğini düşündükleri sonucuna ulaşılmıştır. Nasıl ki bu sonuç ülkemizde yapılan çalışmalarla uyumludur. Altan, Yamak ve Kırıkkaya (2016) yapmış oldukları çalışmada STEM eğitiminin kalıcı öğrenmeler sağladığı, motive edici ve eğlenceli olduğu sonucuna varmışlardır. Sümen ve Çalışıcı (2016) yaptıkları çalışma sonucunda ise STEM etkinliklerinin derse aktif katılımı sağladığı için derslerin daha verimli olduğunu belirtmişlerdir. Ayrıca, Barcelona (2014) yaptığı çalışmada STEM etkinliklerinin öğrencilerin akademik başarılarını arttırdığını ve iyi bir öğrenme pratiği sağladığını belirtmiştir. Bu bağlamda, STEM etkinlikleri ile gerçek yaşam problemlerini çözme tecrübesini edinen öğrenciler, yirmi birinci yüzyıl küresel ekonomisine hazırlanmış olacaklardır (Barcelona, 2014).

Öğretmen adaylarının STEM eğitimleri öğretmenlik kariyerlerine maddi ve manevi anlamda kazanç sağlayacağı, akademik anlamda yükselmelerine katkı sunacağı ve bilgi anlamında daha donanımlı hissedecekleri sonucuna ulaşılmıştır. STEM uygulamaları mesleki uygulamalara yön vererek öğretmen adaylarının profesyonel gelişimlerine ve mesleki yaşantılarına katkı sağlamada oldukça önemlidir (Yalçın, 2011). Yapılan bu çalışma mesleğe katkıları kategorimizi destekler niteliktedir. STEM eğitimlerine katılan öğretmen adayları mesleğe başladığı yıllarda derslerinde daha aktif çalışacak, öğrencilerine bilgileri daha somut bir şekilde vererek daha başarılı bir nesil yetiştireceği düşünülmektedir.

Öğretmen adaylarının STEM uygulamalarının artması için çeşitli önerilerde bulundukları tespit edilmiştir. STEM'in tanınırlığının artmasına dair görüşlerin yanında STEM uygulamaların ayrı bir ders olarak okutulması gerektiği en çok ifade edilen düşünceler arasında yer almaktadır. Öğretmenler ile yapılan bir çalışmada, öğretmenlerin farklı yaklaşımlarla ilgili eğitime gereksinim duydukları sonucuna ulaşılmıştır (Akpınar ve Aydın, 2007). STEM'in tanınırlığının artması konusunda Yamak, Bulut ve Dündar (2014) tarafından çalışmada; STEM eğitiminin gerek okullarda gerekse okul dışındaki aktivitelerde yaygınlaştırılmasının gerekliliği vurgulanmaktadır. Ayrıca öğretmen adaylarının STEM uygulamaları için devlet politikası haline gelip daha başarıları olunabilmesi için bütçeden ek kaynak ayrılması gerektiği sonucuna da ulaşılmaktadır. STEM uygulamalarına gereken desteğin sağlanabilmesi için hükümet yetkililere, okullarda imkanların sağlanabilmesi için MEB yetkililerine, eğitim fakültelerinde imkanların sağlanabilmesi için YÖK yetkililerine büyük iş düşmektedir.

Ayrıca fen bilgisi öğretmen adaylarının fen bilimlerini birçok disiplinle ilişkilendirdikleri görülmüştür. Ayrıca, STEM kavramını tanımlayabilecek yeterlikte oldukları ve STEM uygulamalarını ortaokul fen bilgisi öğretim programına entegre edilmesi gerektiğini düşündükleri belirlenmiştir. Son olarak, katılımcılar STEM uygulamalarının öğrenci ve öğretmen açısından birçok olumlu yönlerinin olduğunu ifade etmişlerdir. 
Sonuç olarak STEM eğitimi almamış, STEM hakkında birtakım algılara sahip olan fen bilgisi öğretmen adaylarının düşünceleriyle, STEM eğitimi alan öğretmen adaylarının düşüncelerinin büyük çoğunluğu paralellik göstermektedir. STEM eğitimini almamış olmanın verdiği duygularla öğretmen adaylarında STEM uygulamalarına örnek verirken çoğunlukla robotik kodlama olarak düşünmelerini, STEM uygulamalarını bir fen konusuna uyarlama durumunda çoğunlukla tasarım yapabileceği konulara yönelmesi, STEM uygulamalarını uygularken çok çaba ve gayret gösterme sonucu yorulma, STEM uygulamaları hakkında var olan bilgi eksikliği nedeniyle korkma ve STEM uygulamalarının maliyetli olduğunu düşünmeleri gibi konularda ön yargılarının olduğu sonucuna varılmıştır. Öğretmenlerin STEM öğretimine yeterince hazırlıklı olamadığı, ön yarg1, öz güven, öz yeterlik inancı eksikliği olduğu vurgulanmıştır (Bleicher, 2006). Başka bir çalışma da ise öğretmenlerin daha önce STEM veya STEM disiplinlerinden birinde deneyimlerinin olması öğretmenler için STEM programını uygularken çok önemli olduğu sonucuna varılmıştır (Van Haneghan, Pruet, Neal-Waltman, ve Harlan, 2015). Yapılan bu çalışmalar sonucumuzu destekler niteliktedir.

$\mathrm{Bu}$ bulgulardan hareketle STEM uygulamalarının anlamlı öğrenmeyi destekleyecek nitelikte olduğu ve öğretmen adaylarında oluşan kavram yanılgılarını ve ön yargılarını gidermek için STEM'in doğası kavramının gerekli derslerde ayrıntılı bir şekilde verilmesi gerekmektedir. Bu sonuca ilave olarak STEM uygulamaları fen bilimleri öğretim programlarında bir ders olarak okutulması gerektiği sonucuna ulaşılmıştır.

\section{Öneriler}

\section{Araştırmacılara Yönelik Öneriler}

Çalışma sonucunda çeşitli öneriler geliştirilmiştir. Araştırmacılara yönelik öneriler aşağıda maddeler halinde belirtilmiştir.

- Yapılan bu araştırma farklı branş öğretmen adayları için yapılabilir.

- Yapılan bu çalışma nicel araştırma yöntemi ile yapılarak sayısal verilerle anlamlandırılabilir.

- Çalışma tek devlet üniversitesinde öğrenim gören fen bilgisi öğretmen adayları ile gerçekleştirilmiştir. Örneklem grubu çeşitlendirilerek ve sayıca artırılarak yeni bir çalışma yapılabilir.

- Bu araştırma okul öncesi, ilkokul, ortaokul ve lise öğrencilerine yönelik olarak da yapilabilir.

- Farklı branştaki öğretmenler iş birliği içerisinde bulunarak, STEM uygulamaları geliştirerek bunların etkilerini inceleyebilir. 


\section{Eğitimcilere Yönelik Öneriler}

Eğitimcilere yönelik öneriler aşağıda maddeler halinde belirtilmiştir.

- Fen bilgisi öğretmenliğinden mezun olan öğretmen adaylarının STEM uygulamaları hakkında belirli bir düzeyde görüşe sahip olmaları için program hazırlayıcılarının, fen bilgisi öğretmenliği öğretim programında STEM uygulamalarına yönelik bir dersin yer alacağı köklü düzenlemeler yapmaları gerektiği düşünülmektedir.

- Öğretim üyeleri, öğretmen ve öğretmen adaylarına STEM uygulamaları hakkında düşünme ve çıkarımlarda bulunma fırsatları veren ortamlar oluşturmalıdırlar.

- Öğretmenlerin iyi birer STEM uygulayıcısı olmaları adına hizmet içi eğitimlerin sayısının arttırılması tavsiye edilirken öğretmen adayları açısından iyi birer STEM uygulayıcısı olmaları adına eğitim fakültelerinde STEM eğitimleri verilmesi tavsiye edilir.

- Fen bilgisi öğretmenliğinden mezun olan öğretmen adaylarının STEM uygulamaları hakkında ileri düzeyde görüş sahibi olmaları için eğitim fakültesindeki, öğretim programının STEM uygulamaları ile desteklenmesi gerektiği önerilebilir.

- STEM eğitimi sadece bir alanı içine alan bir eğitim olmadığı için öğretmen adayları ve öğretmenler kendilerini birçok disiplin açısından yetiştirmeli ve eğitmelidir.

- STEM eğitimi konusunda TÜBİTAK destekli bilimsel çalışmalara teşvikler arttırılabilir.

STEM eğitimini esas alarak öğretim yapmak isteyen öğretmenler için gerekli materyaller tedarik edilmeli, bu tedarik için bir birim oluşturulmalı ve teknik destek sağlanmalıdır.

\section{Kaynaklar}

Akgündüz, D., Ertepınar, H., Ger, A. M., Kaplan Sayi, A., \& Türk, Z. (2015). STEM egitimi calistay raporu: Turkiye STEM egitimi uzerine kapsamli bir degerlendirme (The report of STEM education workshop: an assessment on STEM education in Turkey)[White Paper]. Istanbul, Turkey: Istanbul Aydin University STEM Merkezi ve Egitim Fakultesi.

Alan, B. (2017). Fen bilgisi öğretmen adaylarmın bütünleşik öğretmenlik bilgilerinin desteklenmesi: STEM uygulamalarına hazırlama eğitimi. Yayınlanmamış yüksek lisans tezi, Fırat Üniversitesi, Eğitim Bilimleri Enstitüsü, Elazığ.

Aygen, M. B. (2018). Fen bilgisi öğretmen adaylarının bütünleşik öğretmenlik bilgilerinin desteklenmesine yönelik stem uygulamaları. Yayınlanmamış yüksek lisans tezi, Fırat Üniversitesi, Eğitim Bilimleri Enstitüsü, Elazığ. 
Barakos, L., Lujan, V., \& Strang, C. (2012). Science, technology, engineering, mathematics (STEM): Catalyzing change amid the confusion. Portsmouth, NH: RMC Research Corporation, Center on Instruction.

Barcelona, K. (2014). 21st century curriculum change initiative: A focus on STEM education as an integrated approach to teaching and learning. American Journal of Educational Research, 2(10), 862-875.

Bleicher, R. (2006). Nurturing confidence in preservice elementary science teachers. Journal of Science Teacher Education, 40, 841-860.

Bozkurt Altan, E., Yamak, H. \& Buluş Kırıkkaya, E. (2016). FeTeMM Eğitim Yaklaşımının Öğretmen Eğitiminde Kullanılmasına Yönelik Bir Öneri: Tasarım Temelli Fen Eğitimi. Trakya Üniversitesi Ĕ̆itim Fakültesi Dergisi, 6 (2), 212-232.

Bybee, R. W. (2013). The Case for STEM Education: Challenges and Opportunities. Arlington, Virginia: NSTA Press.

Bybee, R. W., (2010). What is STEM education? Science, 329 (5995), 996: doi: 10.1126/science.1194998

Çorlu, M. S. (2014). FeTeMM eğitimi makale çağrı mektubu. Turkish Journal of Education, 3(1), 4-10.

Çorlu, S. \& Çallı, E., (2017). STEM kuram ve uygulamalarıla fen, teknoloji, mühendislik ve matematik eğitimi. Pusula Yayıncılık ve İletişim: İstanbul.

Dağ, F. (2016). Yaşam boyu öğrenme bağlamında Türkiye'de öğretmenlerin teknolojik yeterliliklerinin geliştirilmesine yönelik mesleki gelişim çalışmalarının incelenmesi. International Journal of Human Sciences, 13(1), 90-111.

Ensari, Ö. (2017). Öğretmen adaylarının FeTeMM eğitimi ve FeTeMM etkinlikleri hakkındaki görüşleri. Yayınlanmamış yüksek lisans tezi, Yüzüncü Yıl Üniversitesi, Eğitim Bilimleri Enstitüsü, Van.

Erduran, S. (2013). Fen bilimlerine alanlar arası bakış ve eğitimde uygulamalar. Fen Bilimleri Ögřetimi Dergisi, 1(1).

Eroğlu, S., \& Bektaş, O. (2016). STEM Eğitimi Almış Fen Bilimleri Öğretmenlerinin Stem Temelli Ders Etkinlikleri Hakkındaki Görüşleri. Ĕ̆itimde Nitel Araştırmalar Dergisi 32- Journal of Qualitative Research in Education, 4(3), 43-67.

Gökbayrak, S, \& Karışan, D. (2017). Altıncı Sını Öğrencilerinin FeTeMM Temelli Etkinlikler Hakkındaki Görüşlerinin İncelenmesi. Alan Eğitimi Araştırmaları Dergisi, 3 (1), 25-40.

Gülgün, C., Yılmaz, A., \& Çağlar, A. (2017). Fen bilimleri dersinde uygulanan STEM etkinliklerinde bulunması gereken nitelikler hakkında öğretmen görüşleri. Journal of Current Researches on Social Sciences, 7(1), 459-478.

Güneş, T., \& Taştan Akdă̆, F. (2017). Lise öğrencilerinin fizik dersine yönelik umutsuzluk düzeyleri. International Journal of Social Sciencesand Education Research, 3(2), 499-507.

Hacioğlu, Y., Yamak, H., \& Kavak, N. (2017). The opinions of prospective science teachers regarding STEM education: The engineering design based science education. Gazi Üniversitesi Gazi Ĕ̆̊itim Fakültesi Dergisi, 37(2), 649-684. 
İnançlı, E., \& Timur, B. (2018). Fen Bilimleri Öğretmen ve Öğretmen Adaylarının Stem Eğitimi Hakkındaki Görüşleri. Uluslararası Bilim ve Eğitim Dergisi, 1(1), 48-68.

Jesus, S. N., \& Lens, W. (2005). An integrated model for the study of teacher motivation. Applied Psychology, 54(1), 119-134.

Kuenzi, J. J., Matthews, C. M., \& Mangan, B. F. (2006, July). Science, technology, engineering, and mathematics (STEM) education issues and legislative options. Library of Congress Washington DC Congressional research service.

Marshall, C. ve Rossman, G.B. (2006). Designing qualitative research (Fourth edition). California: Sage Publications

Milli Eğitim Bakanlı̆̆1 [MEB]. (2006). İlköğretim fen ve teknoloji dersi (6, 7 ve 8. sinıflar) öğretim programi. Ankara: Talim ve Terbiye Kurulu Başkanlığı.

Milli Eğitim Bakanlığ1 [MEB]. (2009). Ortaöğretim 12. sınıf fizik dersi öğretim programı. Ankara: MEB.

Milli Eğitim Bakanlığı [MEB]. (2013). İlköğretim Kurumları (İlkokullar ve Ortaokullar) Fen Bilimleri Dersi (3, 4, 5, 6, 7 ve 8. Sınıflar) Öğretim Programı, Ankara: MEB Yayınevi.

Milli Eğitim Bakanlığ1 [MEB]. (2016). STEM Eğitimi Raporu. Ankara: Milli Eğitim Bakanlı̆̆1 Yenilik ve Eğitim Teknolojileri Genel Müdürlüğü (YEĞİTEK).

Milli Eğitim Bakanlığı [MEB]. (2017). Fen Bilimleri Dersi Öğretim Programı (İlkokul ve ortaokul 3, 4, 5, 6, 7, ve 8. Siniflar). https://bilimakademisi.org/wpcontent/uploads/2017/02/Fen-Bilimleri.pdf. Ankara.

Milli Eğitim Bakanlığı [MEB]. (2018). Fen Bilimleri Dersi Öğretim Programı (İlkokul ve ortaokul 3, 4, 5, 6, 7, ve 8. Siniflar). http://mufredat.meb.gov.tr/ProgramDetay.aspx?PID=325. Ankara.

Morrison, J. (2006). Attributes of STEM education: The student, the school, the classroom. TIES (Teaching Institute for Excellence in STEM).

Özmen, H. (2015). Öğrenme kuramları ve fen bilimleri öğretimindeki uygulamaları. (Edt. S. Çepni). Kuramdan uygulamaya fen ve teknoloji öğretimi. Ankara: Pegem A Yayıncılık.

Sanders, M. (2009). STEM, STEM Education, STEM mania. The Technology Teacher, 20-26.

Sanders, M. \& Wells, J. (2010, February). Integrative STEM education. Paper presented at the Virginia Department of Education Webinar, Integrative STEM/Service learning, year 1.

Sanders, M. E. (2012). Integrative STEM education as "best practice". Griffith Institute for Educational Research, Queensland, Australia.

Selvi, M., \& Yıldırım, B. (2017). STEM öğretme-öğrenme modelleri: 5E öğrenme modeli, proje tabanlı öğrenme ve STEM sos modeli. Pegem Atıf İndeksi, 203- 236.

Seren, S., \& Veli, E. (2018). 2005 yılı itibariyle değişen fen bilimleri dersi öğretim programlarında stem eğitimine yer verilme düzeylerinin karşılaştırılması. Journal of STEAM Education, 1(1), 24-47. 
Siew, N. M., Amir, N., \& Chong, C. L. (2015). The perceptions of pre-service and in-service teachers regarding a project-based STEM approach to teaching science. SpringerPlus, 4(8), 1-20.

Sümen, Ö. Ö., \& Çalisici, H. (2016). Pre-service teachers' mind maps and opinions on STEM education implemented in an environmental literacy course. Educational Sciences: Theory and Practice, 16(2), 459-476.

Tavşancıl, E. \& Aslan, E. (2001). Sözel, yazılı ve diğer materyaller için içerik analizi ve uygulama örnekleri. Epsilon Yayınevi, İstanbul.

Tezel, Ö., \& Yaman, H. (2017). FeTeMM eğitimine yönelik Türkiye' de yapılan çalışmalardan bir derleme. Ĕ̆itim ve Öğretim Araştırmaları Dergisi, 6(1), 135-145.

Thomas, T. A. (2014). Elementary teachers' receptivity to integrated science, technology, engineering, and mathematics (STEM) education in the elementary grades. (Doctoral dissertation). Retrieved from Proquest. (3625770).

Baldi, S., Jin, Y., Skemer, M., Green, P. J., \& Herget, D. (2007). Highlights From PISA 2006: Performance of U.S. 15-Year-Old Students in Science and Mathematics Literacy in an International Context. NCES 2008-016. Washington: National Center for Education Statistics.

Van Haneghan, J., Pruet A. S., Neal-Waltman, R., \& Harlan, M. J. (2015). Teacher beliefs about motivating and teaching students to carry out engineering design challenges: Some initial data. Journal of Pre-College Engineering Education Research, 5(2), 1-9.

Wang, H. (2012). A New era of science education: science teachers' perceptions and classroom practices of science, technology, engineering, and mathematics (STEM) integration. (Doctoral dissertation). Retrieved from Proquest. (3494678).

Yalçın, M. (2011). İlköğretim okullarında okul müdürüne ilişkin metaforik algılar. Yüksek Lisans Tezi, Gaziosmanpaşa Üniversitesi, Eğitim Bilimleri Enstitüsü, Tokat.

Yamak, H., Bulut, N., \& Dündar, S. (2014). 5. sınıf öğrencilerinin bilimsel süreç becerileri ile fene karşı tutumlarına FeTeMM etkinliklerinin etkisi. Gazi Üniversitesi Gazi Ĕ̆itim Fakültesi Dergisi, 34(2), 249-265.

Yenilmez, K., \& Balbağ, M. Z. (2016). Fen bilgisi ve ilköğretim matematik öğretmeni adaylarının STEM'e yönelik tutumları. Journal of Research in Education and Teaching, 5(4), 301-307.

Yıldırım, A. \& Şimşek, H. (2013). Sosyal Bilimlerde Nitel Araştırma Yöntemleri. Genişletilmiş 9. Baskı, Seçkin Yayıncılık, Ankara.

Yıldırım, B., \& Altun, Y. (2015). STEM eğitim ve mühendislik uygulamalarının fen bilgisi laboratuar dersindeki etkilerinin incelenmesi. El-Cezeri Journal of Science and Engineering, 2(2), 28-40.

Yıldırım, B., Şahin, E., \& Tabaru, G. (2017). STEM uygulamalarının öğretmen adaylarının bilimin doğası inançları, bilimsel araştırma ve yapılandırmacı yaklaşıma yönelik tutumları üzerindeki etkisi. International Congress Of Eurasian Social Sciences (ICOESS) Özel Sayısl, 8(8), 16-29. 
Yılmaz, N., \& Pekbay, C. (2017). Fen Bilgisi ve İlköğretim Matematik Öğretmen Adaylarıyla Yapılan Bir FeTeMM Etkinliğinin Tanıtılması Üzerine Bir Çalışma. In ICPESS (International Congress on Politic, Economic and Social Studies) (No. 2, pp. 512-513).

\section{EK:1 Görüşme Soruları}

1. Sizce fen bilimleri hangi disiplinlerle ilişkilidir?

Sonda: Fen bilimleri ile teknoloji, mühendislik ve matematik alanları arasında nasıl bir ilişki vardır?

2. STEM kavramını nasıl tanımlarsınız? Örnek verebilir misiniz?

3. Fakültedeki alan, laboratuvar ve alan eğitimi derslerinizin STEM uygulamaları ile işlenmesini ister miydiniz? Neden?

4. Fakültelere "STEM uygulamaları" isimli bir ders fen programina konulmalı midır? Neden?

5. STEM eğitimlerinin size ne gibi katkılarının olacağını düşünüyorsunuz?

6. Meslek hayatınıza başladığınızda STEM uygulamalarının dersinizde işinizi kolaylaştıracağını düşünüyor musunuz? Neden?

7. Meslek hayatınıza başladığınızda STEM uygulamaları ile ders işlemek motivasyonunuzu nasıl etkiler?

8. STEM uygulamalarının hangi fen derslerine daha uygun olduğunu düşünüyorsunuz?

9. STEM uygulamalarını ilköğretim fen konuları dikkate alındığında hangisine uyarlardın? Nasil?

10. Öğretmen açısından fen bilimleri derslerinde STEM uygulamaları kullanmanın avantajları ve dezavantajları nelerdir?

11. Öğrenci açısından fen bilimleri derslerinde STEM uygulamaları kullanmanın avantajları nelerdir?

12. STEM eğitiminin öğretmenlik kariyerinize ne gibi katkılarının olacağını düşünüyorsunuz?

13. STEM uygulamalarının artması için nasıl çalışmalar yapılmalıdır? 